\title{
Aristotle on Virtue of Character and the Authority of Reason
}

\author{
Jozef Müller \\ Department of Philosophy, University of California, Riverside \\ HMNSS Building, Room 1604, 900 University Avenue, Riverside, CA 92521. USA. \\ jozef.muller@ucr.edu
}

\begin{abstract}
I argue that, for Aristotle, virtue of character is a state of the non-rational part of the soul that makes one prone to making and acting on decisions in virtue of that part's standing in the right relation to (correct) reason, namely, a relation that qualifies the agent as a true self-lover. In effect, this central feature of virtue of character is nothing else than love of practical wisdom. As I argue, it not only explains how reason can hold direct authority over non-rational desires but also why Aristotle defines virtue of character as hexis prohairetikē.
\end{abstract}

\section{Keywords}

Aristotle; moral virtue; character; desire; reason; decision

\section{I}

In both the Nicomachean and the Eudemian Ethics, Aristotle divides the human soul into the rational (to logon echon) and the non-rational (to alogon) part. ${ }^{1}$ Although the details of this division are contested, ${ }^{2}$ there is a general agreement that the rational part is or contains reason (and so that it

${ }^{1} N E$ 1.13, 1102a28; EE 2.1, 1220a8-11; Pol. 7.14, 1333a16-27. In DA 3.9, Aristotle raises numerous problems for theories that would divide the soul into parts. Nevertheless, he often uses the language of 'parts' when talking about various functions, aspects, or powers of the soul (e.g. $N E$ $1.13,1102 \mathrm{~b} 4 ; E E 2.1,1220 \mathrm{a} 2)$. Concerning the division into two parts in the ethical works, he tells us that it is a functional division, capturing a distinction that is relevant for ethical and political purposes. In the $N E$, he outlines two options concerning the ontological status of the division: the parts could be separate (in the way in which two parts of the body are separate), or inseparable but different in account 'like the convex and the concave in a curved surface' (1102a28-31). As he tells us, for the purposes of ethics and politics, it does not matter which of these options is true. In the $E E$, he adds that what matters is that the soul has different capacities (corresponding to the division) rather than whether the soul really has two parts $(1219 \mathrm{~b} 28-37)$. I will return to the nature of the division later in the paper.

${ }^{2}$ The disagreement concerns primarily the content of the non-rational part which Aristotle also describes as 'the appetitive and in general desiderative' part (NE 1.13, 1102a29-31): does it contain 
is capable of thinking) and that the non-rational part contains non-rational desires (i.e. appetite and spirit). It is also clear that, on Aristotle's view, the virtuous disposition of character involves harmonizing the two parts in such a way that they become in some sense unified with respect to actions and feelings: they are supposed to 'chime together' (homophōnei) (NE 1.13, 1102b29-30). This means that, in an appropriately unified soul, the non-rational part does not merely happen to desire what the rational part prescribes but desires it somehow as a result of the rational part prescribing it ( $N E 1.13,1102 \mathrm{~b} 33-1103 \mathrm{a} 1)$. The virtuous agent is supposed to guide and direct not only her actions but also her inner life (including her non-rational desires and feelings) by reason in a distinct way so that her whole soul aims at the right things (e.g. NE 3.12, 1119b15-17).

The harmonization of the two parts as Aristotle requires it seems, however, difficult to understand. On Aristotle's view, non-rational desires and feelings are based on perceptual (including phantasia-based) pleasure and pain (e.g. DA 3.7, 431a8-16), whereas reason forms judgments and corresponding (rational) desires on the basis of considerations of goodness (e.g. $N E$ $3.4,1113 \mathrm{a} 22-1113 \mathrm{~b} 2 ; 5.9,1136 \mathrm{~b} 6-9)$. Consequently, many scholars think that the twofold division of the soul in the ethical works is related to the division between the perceptual and the intellectual soul found in the De anima. ${ }^{3}$ In particular, they think that the non-rational part's cognitive capabilities are exhausted by those that Aristotle attributes to (human) perception (including phantasia). ${ }^{4}$ Since finding something perceptually pleasant (or painful) seems independent of whether one judges it to be good or bad, they conclude that reason cannot influence non-rational desires directly, that is, simply in virtue of making a judgment about the goodness or, in general, desirability of something.

Most scholars have thus adopted the view that one's rational judgment that $x$ is good (pleasant, fine etc.) or bad (painful, shameful etc.) can influence non-rational desires only if one already finds or experiences $x$ as pleasant or painful. ${ }^{5}$ Even in the virtuous agent, reason can only bring something into the (perceptual) cognitive focus of non-rational desires - whether they react to

all kinds of desire (wish, spirit, appetite) or only the two non-rational kinds (i.e. spirit and appetite)? For further discussion, see Price 2011a, 121-2; Lorenz 2009, 183; Moss 2012, 71-4.

${ }^{3}$ William Fortenbaugh (2002, 26-30)has argued against the association of the non-rational part as it is distinguished in the ethical works with the perceptual part in the $D A$. His argument is however undermined by his claim that human perception (as a biological faculty) does not differ from animal one.

${ }^{4}$ See, for example, Moss 2012, 71-4; Pakaluk 2005, 92-4; Lorenz 2006, 189; Price 2011a, 118-23.

${ }^{5}$ See, for example, Lorenz 2006, 189-90; Moss 2012, 71-4 and 94-8. 
it depends on whether they find it independently pleasant or painful. ${ }^{6}$ When reason issues a command and non-rational desires follow it, they do so not because of the command itself but, rather, because through commanding them reason has directed their attention to, or informed them about, something that they have already come to enjoy or find painful, usually through a long-term process of habituation. But since it is not possible to always already enjoy (or find painful) what reason commands, additional work by reason is often required - it needs to stir the non-rational desires in the direction it proposes by offering them additional incentives (e.g. it directs their attention to the pleasant consequences of the proposed action). ${ }^{7}$ In short, reason's influence amounts to a kind of manipulation. ${ }^{8}$

However, a number of Aristotle's claims strongly imply, if not outright express, a rather different view about the interaction between the virtuous person's reason and his or her non-rational desires. The idea seems to be that non-rational desires, once properly habituated, come to accept reason's prescriptions, that is, come to desire (or otherwise relate to) things directly as the result of reason prescribing it. When Aristotle describes the relationship between non-rational desires and reason, he tells us that in the virtuous agent the non-rational part lives according to reason in the same way in which children live according to their fathers or tutors $(N E 1.13,1102 \mathrm{~b} 31-2 ; 3.12$,

${ }^{6}$ Commenting on $N E$ 6.2, 1139a21-26, Carlo Natali $(2016,173)$ thus can write that: 'Désir et raison sont unis du fait que tous deux ont un accès cognitif indépendant à un seul et même objet, un bien qu'il nous est possible de réaliser ici et maintenant.'

${ }^{7}$ As Hendrik Lorenz explains: 'As far as appetite is concerned, its attention may be redirected from the pleasure that seems imminent to some other prospective pleasure ('encouragement'), or to some prospective pain ('admonition' or 'warning'). Similarly, it should be possible to move spirit by drawing its attention to shameful or otherwise unseemly aspects ('reprimanding'), or alternatively to fine or admirable aspects (another form of 'encouragement'). In these various ways, an intense occurrent non-rational desire may grow or less intense, or may subside altogether . . . The virtuous person's appetitive desires ... are as they are because the virtuous person has learned to take pleasure in those things, and only in those things, that one should take pleasure in, and in those ways, and only in those ways, that one should take pleasure in them' (Lorenz 2006, 189-90).

${ }^{8}$ The idea is essentially that of synchronic self-control. Classic examples include people who control their urge to smoke by focusing on the potentially painful results of smoking, or people who control their sexual desire by focusing on sexually unattractive things. Synchronic self-control is usually contrasted with diachronic self-control in which one attempts to manipulate one's environment or thoughts prior to a possible temptation. For classic contemporary discussion of the problem of synchronic self-control (as well as its relation to diachronic self-control), see Kennett and Smith 1996; Mele 1997; Sripada 2014. It is noteworthy that in psychological experiments, selfcontrol through a process of the kind attributed to Aristotle (by Lorenz 2006 and others) is usually treated as a case of distraction rather than a case of genuine (direct) self-control. See Winters, Christoff and Gorzalka 2009. 
$1119 \mathrm{~b} 12-5$. The non-rational part obeys the prescriptions or commands of reason, accepting its authority, just as a child accepts the authority of his or her father, or a servant that of his master (NE $5.11,1138 \mathrm{~b} 11)$. The implication of this description is clear: in the virtuous agent, the non-rational part accepts reason's commands directly. The authority of the father over his children (or of the master over his servants) does not rest on his ability (which he might well have and occasionally use) to get them to do something he commands by somehow tricking them to do that (say, by offering them something else in exchange). Similarly, we are not supposed to think that reason needs to 'offer' the non-rational part any incentives to elicit its cooperation (even if it might be capable of doing so). Rather, the virtuous agent guides and directs not only her actions but also her inner life (including her non-rational desires and feelings) by reason in a distinct way so that her whole soul aims at the right things (e.g. NE 3.5, 1114b26-8; 3.12, 1119b15-17; 3.7, 1115b11-12; $4.5,1125 \mathrm{~b} 35 ; 6.2,1139 \mathrm{a} 25-6)$. For example, the brave person 'acts and feels in accordance with what things are worth, that is, as reason prescribes' $(3.7,1115 \mathrm{~b} 19-20)$, while the temperate person adjusts his appetitive desires as reason orders $(3.11,1119 \mathrm{a} 20)$. In general, Aristotle emphasizes that virtue of character ensures that one's non-rational desires do not merely happen to be directed at what reason prescribes but do so (somehow) along with or on account of the activity of reason (NE $6.13,1144 \mathrm{~b} 26-32)$. He makes it a central tenet of his ethical theory that, in a virtuous person, reason and non-rational desires become related quite intimately, so that what reason asserts they desire precisely because reason asserts it (NE 6.2,1139a22-36) and not merely because something they already find attractive has come into their cognitive focus and it just so happens that it did so because of reason. ${ }^{9}$

The problem is that it is not obvious how to account for such statements in view of the presumed independence of non-rational desires from the judgments of reason and their association with perceptual pleasure and pain. In this paper, I develop an interpretation which explains how Aristotle can think that reason can exercise direct authority over non-rational desires, albeit only in the virtuous agent. The interpretation does so in virtue of a mechanism for developing the natural capacities of the non-rational part that Aristotle himself prefers, namely habituation. On the proposed account, it is neither the case that reason rationally persuades non-rational desires (i.e. on ${ }^{9}$ So already Richard Loening $(1903,115)$ says: 'Zur Tugend genügt es nicht, wenn das Begehren und Handeln, etwa auf Grund natürlicher Triebe, mit den Anforderugen der Vernunft tatsächlich,

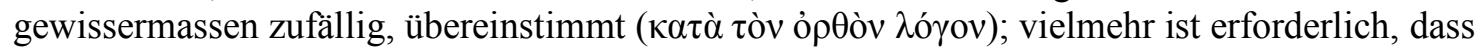

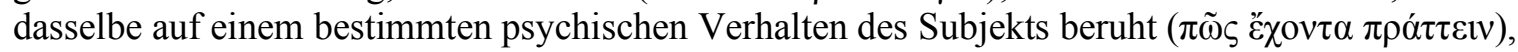

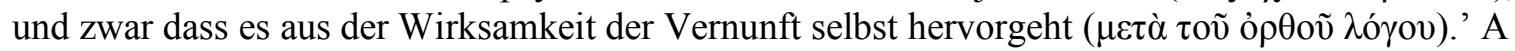
similar point, from a slightly different point of view, is made also by Curzer 2002, 147. 
the basis of reasons), nor that, as a consequence of habituation to the correct external things, the non-rational desire merely always already happens to desire what reason says they should desire. Rather, the non-rational part of the virtuous agent is sensitive to what reason says because of their habitual attachment to (their own) true deliberative efforts and decisions.

A significant benefit of the interpretation is that it simultaneously sheds new light on Aristotle's definition of virtue of character as a hexis prohairetike.$^{10}$ The definition is subject to the following exegetical problem. Since Aristotle tells us that (1) virtue of character is primarily (if not exclusively) the excellent state of one's non-rational desires and feelings, ${ }^{11}$ and that (2) virtue of character is essentially such that it issues in decisions (i.e. that it is a hexis prohairetike e) ${ }^{12}$ then it follows that (3) decisions are the results of non-rational desires or, alternatively, that non-rational desires make essential contribution to the virtuous person's decisions. But according to the standard conception of decision, (4) decisions are the results only of rational states and processes (i.e. wish and deliberation). They are psychological acts or states that result from successful deliberation about what action would best promote an end which is desired in virtue of its being conceived of as good by the agent. An end of this sort is the object of the rational kind of desire that Aristotle calls

${ }^{10} N E$ 2.6, 1106b36-1107a2; $E E$ 2.10, 1227b8; and $N E 6.2$ / EE 5.2, 1139a23. In the EE, Aristotle states that virtue is prohairetike several times but without adding that it is a state $(E E 3.1,1228 \mathrm{a} 25$ and 1230a25).

${ }^{11}$ There is a disagreement about whether in the NE Aristotle thinks that virtue of character is the virtue of only the non-rational part of the soul or of both the rational and the non-rational part of the soul, as these are distinguished in NE 1.13 and EE 2.1. See Moss 2012 for the former, and Lorenz 2009 for the latter view. In the $E E$, virtue of character is the best state of the non-rational part of the soul $(E E 2.1,1220 \mathrm{a} 5-13 ; 2.4,1221 \mathrm{~b} 27-34)$.

12 The general meaning of prohairetikos, suggested by the -ikos ending, is something like 'concerned with decision'. But that allows for a number of different interpretations of hexis prohairetike : (1) it is a state whose activity or actualization is decision (as theōria is the activity of reason that is theōrêtikos); (2) it is a state that results from decisions (in the same way in which prohairesis is said to be a bouleutike orexis, that is, a desire that results from deliberation); (3) it is a state in which that which it is the state of (i.e. the non-rational part of the soul) follows one's prohaireseis (in the same way in which doctors who are dogmatikoi are said to be such because they follow certain doctrines); (4) it is a state of one's soul which makes one capable or suited for making decisions (in the same way in which epistemmē is a hexis apodeiktikē, that is, a state that makes one capable of making demonstrations or proofs; (5) it is a state which makes one prone to making decisions (in the same way in which, say, someone who is hamartetikos is prone to making errors); or (6) it is state which is ultimately realized in decisions. Scholars have defended many of these positions: Pakaluk 2005 adopts aspects of (1); Kosman 1980 argues in favor of (2); Lorenz 2009 defends (4); and Moss 2012 adopts aspects of (6). In this paper, I argue that the meaning of hexis prohairetike is closest to option (5) combined with option (3). 
wish (boulesis). ${ }^{13}$ Decisions are thus rational motivational states that are based on rational cognition and rational volition only. ${ }^{14}$ The role that decision is supposed to play in the definition of virtue of character is thus not obviously compatible with the standard understanding of what decisions, on Aristotle's view, are. In other words, claims (1), (2), (3) and (4) appear to be inconsistent.

The problem has been recognized in the literature, even if it has not been made as explicit as I have done above. ${ }^{15}$ Most frequently, it arises when scholars try to explain the connection

${ }^{13}$ For the division of desires into rational and non-rational ones, see $D A 432 \mathrm{~b} 5-6$; Rhet. 1368b371369a7; and Top. 126a3-13. In the NE, the division is clearly implied at many places (e.g. 1102b13$1103 \mathrm{a} 3$ or $1111 \mathrm{a} 27-\mathrm{b} 13$ ). For the divisions of desire (orexis) into three kinds, see especially $D A$ 414b2; EE 1223a27 and 1225b25. Unlike appetite and spirit, which are desires that are primarily aroused by perceiving (or imagining) something in a pleasant or painful way (DA 431a8-14), wish is aroused by thinking or judging that something is good (EE 2.10, 1227a29-32; NE 3.5, 1113b23-7) when such thought or judgment is accompanied by a sincere belief that what one judges to be good must or should be attained (EE 1226a14-15). It is thus said to originate in the reasoning part or aspect of the soul (en toi logistikōi) (DA 432b5; Top. 4.5, 126a13) rather than (as the non-rational desires do) in the non-rational part or aspect of the soul (en tōi alogōi). Although this is the generally accepted view, several scholars argue that wish is to be placed in the non-rational part of the soul, along with the other desires. Some argue, mainly on the basis of EE $2.41221 \mathrm{~b} 30-2$, that this is Aristotle's view in the $E E$ but do not extend their claim to other works (e.g. Corcilius 2008, 170). Others argue that it is Aristotle's view in general: Moss 2012, 162; Liu 2012, 541-3 and 2016, 61-5. Liu's argument rests, among other things, on interpreting (controversially) $D A$ 432a22-b7 as suggesting that the desiderative part cannot be divided at all since the consequence of such division, namely that wish would belong to the rational part, is said to be absurd. Thus wish must belong to the undivided (and indivisible) desiderative part which is, in turn, identical to the non-rational part distinguished in $N E$ 1.13. Both Moss and Liu also rely on Pol. 7.15, 1334b22-5, where wish is listed, alongside appetite and spirit, as a desire that human beings have right from birth. This would suggest that wish belongs to the non-rational part of the soul since, as the passage asserts, reason is not present at birth and develops only later in life. But other interpretative options are available that make the passage more consistent with Aristotle's thought elsewhere. For example, it might well be that some desires even of infants are not explicable on the basis of pleasure alone. One could point to the desire to learn, manifested in the curiosity of infants that leads them to repeatedly put even obviously unpleasant objects into their mouth (something other animals would not do repeatedly). This behavior cannot be attributed to pleasure-based desire (such as appetite or spirit), and so one might think that we can only explain it as stemming from an innate desire to know, which is a desire for something good rather than pleasant. The wishes of infants and small children, then, just like their reason, are present only in a rudimentary, immature (ateless) way. For further discussion of the issue, esp. as it relates to prohairesis, see Price 2011a, 120-2.

${ }^{14}$ This view of decision can be traced back to Anscombe 1965. The widespread (even if not universal) acceptance of Anscombe's interpretation makes it impractical to list all its supporters but see: Sorabji 1980; Mele 1981; Cooper 1999b; Gourinat 2002; Pakaluk 2005; Lorenz 2009; Segvić 2009; Price 2011a.

${ }^{15}$ Pierre-Marie Morel offers a slightly different version of the puzzle. He focuses on the fact that the definition of virtue of character at $N E$ 2.6, 1106b36-1107a8 invokes the phronimos (i.e. the 
between two of Aristotle's requirements for genuinely virtuous actions, namely (a) that the virtuous person enjoys them and (b) that she decides on them for their own sake or for themselves. Aristotle presents these requirements in a way that strongly implies that they go hand in hand but he does not explicitly tell us how we are to understand their relation. A standard way of relating the conditions maintains that the virtuous agent's decision to perform her virtuous actions for their own sake is enabled by, or comprehensible in view of, the fact that the virtuous person enjoys the action (or, rather, the activity involved in the action). ${ }^{16}$

The thesis seems intuitively plausible. For example, if someone decides to go and see an opera and does so in the absence of any ulterior or external motives (such as impressing one's romantic interest or doing it as part of a charity event), then it seems that his or her decision can only make sense if he or she enjoys opera. However, the thesis merely sidesteps rather than solves the exegetical problem. If decision is the result of deliberation about how to promote a rational desire (i.e. wish), how does the fact that one enjoys a given activity and does so non-rationally (since, as is made clear in $N E 2.3,1104 \mathrm{~b} 4-12$, the required enjoyment is due to one's character) contribute to, and so help to explain, one's deciding on the activity for its own sake? One way in which it could do so would be if pleasure were the reason why one decided on the action, that is, if pleasure were what one wished to get out of the activity. But although it might be that sometimes pleasure can be the reason why one decides on an action for its own sake, it cannot be so in all cases. ${ }^{17}$ Aristotle emphasizes that virtuous actions are decided on and done for the sake of the fine and not for the sake of pleasure (even if the virtuous agent does find them pleasant) (e.g. NE 3.8, 1117a6-9; 4.1, 1121a30-b10). Moreover, he allows that at least sometimes a virtuous person might not find her virtuous action pleasant. For example, the brave person will choose a brave action even if she finds it painful (NE 3.9, 1117b1-17). This assertion seems to support the view that one can decide on an action for its own sake quite independently of whether one also looks forward or enjoys the (prospect of the) action. Thus it cannot be a presupposition of deciding on an action for

practically wise person). The definition thus directly connects virtue of character to practical wisdom and this might lead to the blurring of the distinction between virtue of character and practical wisdom (Morel 2017, 145). Similarly, Lucas Angioni remarks that, since virtue of character is concerned with ends of actions whereas decision is concerned with the means (i.e. the actions) by which one achieves them, the definition of virtue of character in terms of decisions seems to lead to 'moral virtue invading the territory of phronessis' (Angioni 2009, 10).

${ }^{16}$ See, for example, Burnyeat 1980 or Hutchinson 1986, 102.

${ }^{17}$ I explore the implications of cases where it can in Müller 2016. 
its own sake that one enjoys it. And yet Aristotle sees such decisions as somehow flowing from the virtuous disposition of one's character, that is, among other things, from the virtuous state of one's capacity for feelings.

The proposed interpretation of the interaction between the virtuous person's reason and non-rational desires makes it possible to solve this problem. ${ }^{18}$ As I will argue, virtue of character is primarily the state of the non-rational part of the soul that makes one disposed to enjoy and engage in true or correct reasoning about how to act and in which one forms non-rational attachments to the results of one's deliberative efforts, that is, one's decisions. The virtuous person is prone to making, and enjoys following upon her thoughtful decisions about her life and actions (e.g. $N E$ 6.5, 1140a31). As Aristotle explains, virtue of character makes one deliberate and decide (e.g. EE 3.1, 1230a27-32). In effect, this central feature of virtue of character is nothing else than love of practical wisdom.

II

Interpretative Strategies in the Literature

${ }^{18}$ Following Irwin 1975, Hendrik Lorenz $(2009,200)$ argues that virtue of character is 'a unified dispositional state combining the virtuous person's disposition to adopt ends and phronessis'. Since, on this view, virtue of character involves practical wisdom and decisions are the results of successful deliberation about wished-for ends, virtue of character can be said to issue in decisions. One problem with this interpretation is that it is only available within the context of the $N E$. In the $E E$, Aristotle is explicit about virtue of character being the best state of exclusively the non-rational part of the soul (EE 2.1, 1220a5-13; EE 2.2, 1220b5-7; 2.4, 1221b27-34). Since, however, in the $E E$ Aristotle also subscribes to the view that virtue of character is a state that issues in decisions, one would have to claim that Aristotle operates with a different conception of decision in the $E E$ than in the $N E$. Another problem is that the interpretation does not make clear how the two aspects of virtue of character relate to each other, making the notion of virtue of character lack appropriate unity. An analogy might help to see the problem. Let us divide tree into two parts: trunk (i.e. the part that involves all woody elements, including the roots) and foliage (i.e. the part that includes green and soft structures, such as leaves and flowers). Now if photosynthesis is solely the work of foliage, then a definition of trunk as that which is 'productive of photosynthesis' seems mistaken. Even if foliage needs trunk to physically support it, trunk's role or work (ergon) in supporting it is not plausibly characterized as 'productive of photosynthesis'. Arguing that the trunk part includes foliage would not help since the definition would still not relate to the non-foliage parts of the trunk that make it a trunk. Hence, it would also fail to identify how the two aspects of the (redefined) trunk (i.e. the woody elements and the foliage) relate to each other. If the definition is to stand, we need to understand how trunk as such (i.e. non-foliage) contributes to the actual process of photosynthesis and does so in a way that defines its being a trunk. Similarly, Aristotle's definition of virtue of character in terms of decisions implies that non-rational desires contribute to (or play a part in) decisions and that that contribution is central and essential to what virtue of character (as opposed to practical wisdom) is. 
Scholars who proposed accounts of reason's influence on non-rational desires that go beyond mere manipulation (in the way explained above) have explored two different lines of argument. One the one hand, some have argued that the cognitive abilities of the non-rational part must go beyond perceptual (and phantasia-related) capabilities. ${ }^{19}$ A prominent view along these lines has been developed by John Cooper (1999b). On Cooper's interpretation, non-rational desires can be 'in a way persuaded by reason' because the conative element of the non-rational part of the soul is sensitive not only to perceptual pleasure and pain but also to thoughts about goodness or badness. On his view, the non-rational part is sensitive to them because it contains such thoughts. ${ }^{20}$ Reason can thus 'persuade' non-rational desires since it can make them adopt its view about what is good $(1999 b, 245)$. However, since non-rational desires are not sensitive to reasons for holding such views (or thinking such thoughts), the persuasion does not proceed through argument but rather through drawing the attention of non-rational desires to various relevant features or facts that can make them adopt the view that reason already holds. A non-rational desire will, on this view, be persuaded by reason to adopt its view but only insofar as reason has drawn its attention to some feature(s), facts, or consequences of whatever it is that is at stake so that it can change its view 'on its own ground' (ib.) rather than by whatever reasons reason has for holding the view.

A significant problem for an interpretation along these lines is that, despite Cooper's insistence to the contrary, the procedure of persuasion (as Cooper describes it) seems to require that the source of non-rational desires recognizes reasons for changing its views about the desirability of whatever it is that is at stake. If one has an appetitive desire for something because one thinks that that thing is good then, if one changes that view or thought in virtue of having drawn one's attention to some further relevant pleasant or painful fact, it seems fair to describe such a change of view as being based on recognition of reasons (even if it is not part of the mechanism of changing the view that one conceptualizes those reasons as reasons). On Cooper's view, it cannot be that reason's drawing the attention to some relevant further fact simply causes the change of one's non-rational desire, since the desire is supposed to rest on a thought about its object (but not this further fact) being good. The non-rational desire thus must change its view about the goodness of the relevant

${ }^{19}$ For example, Gavin Lawrence $(2011,244)$ writes: 'This part then, in a human, is amenable to reason; its good states essentially involve its ability to listen to reason, to follow it - not simply to be trained as to accord, chime, or harmonize with it (see for example 2.6, 1106b36-1107a2). It is thus essentially reason-learning, and, when properly developed, becomes fully intertwined with, or illuminated by, reason ('with' not merely 'in accord': 1144b26-32).' See also Charles 2015, 84.

${ }^{20}$ This feature of Cooper's account distinguishes it from the one found in Lorenz 2006. 
object or course of action in view of that further fact. But this threatens the distinction between the rational and the non-rational part of the soul: for if the non-rational part can recognize reasons, in what way can it be said to be non-rational? ${ }^{21}$

Some scholars have thus explored another strategy, finding inspiration in Aristotle's frequent pronouncements that the virtuous person 'acts for the sake of the fine (to kalon)', ${ }^{22}$ and in the less frequent claim that both the virtuous person's reason and his non-rational desires aim at the fine (e.g. $N E 3.12,1119 \mathrm{~b} 16)$. The basic idea is to bridge the gap between reason and non-rational desires by a shared value (namely, the fine) to which both parts can come to relate, one part through understanding, the other through habituation. For example, David Smith argues that 'To be motivated by anything other than pleasure or pain is to follow reason' and that it is part of good habituation or upbringing that young people start 'to want things other than pleasure and to take satisfaction in the active pursuit of such' (Smith 1996, 70-1). The goal of habituation is then the instilling of 'a concern for what is fine', where 'the fine' is taken to refer to 'any practical object of valuation other than pleasure' (ib.). Thus, on Smith's view: 'Reason bids us not to be motivated by pleasure as such, or, more generally, by the pleasure-pain nexus that is specific to passion. We have seen that not to be thus motivated is to be motivated by reason for the sake of what is fine' (72).

Unfortunately, Smith does not explain what it means for non-rational desires to be motivated by the fine beyond contrasting such motivation with motivation by pleasure. ${ }^{23}$ But this

${ }^{21}$ Similar criticism of Cooper's view can be found in Grönroos 2007, 254-5. Cooper's view also presupposes that non-rational desires can contain thoughts or beliefs concerning the goodness and badness of things. Concerning appetite, he claims that this view is implied by Aristotle's 'frequent claim that its object, the pleasant, is the apparent good' (Cooper 1999b, 243). As he understands the claim, when one experiences an appetite for something, that is, when one finds it pleasant, one 'takes it to be good' which he explicates as coming to think that 'it would be good to have it in whatever way one desires it' (ib.) where such thought is part of one's appetitive desire. Although I cannot examine this view in detail, it should be noted that Aristotle denies that the non-rational part contains beliefs (EE 7.2, 1235b28-9) and so seems to exclude beliefs from being parts of nonrational desires and feelings even if, presumably, desires and beliefs can and do interact with each other. On this issue, see Price 2011a, 113-22.

${ }^{22}$ For example, $N E$ 4.1, 1120a19-20; NE 3.6, 1115b2-3; 4.2, 1122b6-7; 4.6, 1127a6; 9.8, 1168a335.

${ }^{23}$ One possibility has been explored by Gösta Grönroos who argues that, although reason cannot directly influence appetite, it can have a more direct effect on spirit since they are both desires that care, albeit in different ways, about the fine (as opposed to pleasure). However, there is little evidence to support the claim that spirit is a desire that 'only requires stimulation by means of exposure to the fine in order to be activated' (Grönroos 2007, 265 n. 31). The one text (Pol. 7.15, 1334b22-5) that Grönroos appeals in support for this view, only asserts that it is an inborn desire, 
contrast might well be misleading, since the idea might very well be that non-rational desires are motivated by the fine because they have become habituated so as to find the fine things (whatever those are) pleasant. ${ }^{24}$ But if that is so, his view collapses into the view that reason can only influence non-rational desires indirectly (by directing their attention to what they find pleasant or painful) and so fails to account for the kind of direct influence of non-rational desires by reason that Aristotle so often highlights.

\section{Overview of the Proposed Interpretation}

A common feature of the interpretations just discussed is that they assume that, when Aristotle talks of human non-rational desires as capable of being 'in a way' persuaded by reason, he is referring to some basic, natural (i.e. not acquired or developed) feature of those desires. Hence, any type of agent (virtuous, self-controlled, uncontrolled, vicious) can, in principle, engage in the 'persuasion' (however one interprets it) of her non-rational desires. This assumption is especially notable in the way in which, for example, Cooper $1999 b$ or Lorenz 2006 find evidence for the mechanism of rational control of such desires: it comes, to a large extent, from Aristotle's discussion of uncontrolled desires. ${ }^{25}$ However, nothing that Aristotle says necessitates the view that all types of

not that it is a desire for the fine. In fact, there is good textual evidence to associate spirit with pleasure and pain rather than with the fine $(E E 2.8,1223 \mathrm{~b} 19-28 ; 2.10,1225 \mathrm{~b} 30-1 ; N E 3.8,1117 \mathrm{a} 7)$, as well as evidence that contrasts the agent's motivation for acting for the sake of the fine with the contribution of spirit $(N E 3.8,1116 \mathrm{~b} 30-1)$. Grönroos also takes Aristotle's remark that 'spirit follows reason in a way, but appetite does not' $(N E$ 6.6, 1149a32-b1) to pertain to the general relationship between reason and, respectively, spirit and appetite. However, the remark comes from Aristotle's discussion of akrasia and it is, quite clearly, meant to apply to uncontrolled spirit and appetite. That is, it is meant to be read as saying that, when one acts akratically from a spirited desire, one in a way follows reason, but when one so acts from appetite, one does not. There is a further question as to what this means, but whatever it means one cannot directly generalize from this statement to either general features of spirit and appetite or to the special features of virtuous spirit and appetite.

${ }^{24}$ This is rightly pointed by Moss 2012, 210-11.

${ }^{25}$ Hendrik Lorenz $(2006,195)$ writes that Aristotle's account of the human soul in Nicomachean Ethics 1.13 'makes clear that he takes the non-rational part or aspect of the soul that is the origin of appetitive and spirited desires to be capable of obeying, and of listening to, reason. This is illustrated by the way the non-rational part acquiesces in the better course of action when a person acts with self-control. As far as appetite is concerned, I suggested that "persuasion" may come about by reason directing appetite's attention away from the pleasure of the moment towards something else that may capture its interest - say, the prospect of a greater and more engaging pleasure, or a prospect of intense pain (We can now see that this may simply be an exercise of 
agent exercise the same kind of control over their non-rational desires. In fact, as the passages referred to in Section I above indicate, most if not all of Aristotle's statements that concern the way in which reason can command non-rational desires (or the way in which those desires 'listen' to reason) either pertain specifically to the virtuous agent or single out the virtuous agent as having a special, harmonious relationship between reason and the non-rational part of the soul. Moreover, Aristotle's claim, in $N E 1.13$ and $E E 2.1$, to the effect that the non-rational part of the human soul is such as to listen and obey reason 'by nature' need not be understood as pointing to some fixed, ever-present feature of human non-rational desires. Rather, the sense of 'by nature' can very well be the one according to which human non-rational desires have a capacity to develop in such a way that they can listen to reason (i.e. become virtuous).

Once we abandon the assumption that the way in which reason can influence non-rational desires is available to all types of agents, it becomes pertinent to ask whether Aristotle provides us with an account of the relationship of the virtuous agent to her reason that would enable us to see how the virtuous agent can exercise direct control over her non-rational desires. I will argue that Aristotle does precisely that in his account of the virtuous person as a self-lover insofar as virtuous self-love involves a non-rational attachment to true reason and intellectual activities. The virtuous person finds (non-rationally) pleasant not only the various correct external things with which her actions are concerned (e.g. the right kinds of food), but also (and, in fact, primarily) her internal intellectual activities, in particular her deliberative processes. She is the kind of person who loves, and so feels a need to think or deliberate about what to do whenever that is possible and appropriate. She is the lover of correct reason and reasoning and 'for each person that which he is said to be the lover of is pleasant' $(N E 1.8,1099 \mathrm{a} 7-8)$.

The claim that non-rational desires can take as their objects intellectual activities is a crucial part of this interpretation. ${ }^{26}$ As I argue, one particular way in which they can come to do so is through the development of a habit of engaging in intellectual activities where that habit involves an attachment to intrinsic features of those activities. Since the intellectual activities in question are those of deliberation or practical reasoning, the habit in question is one of subjecting one's non-

reason's ability to inform appetite about available sources of pleasure)'. See also Cooper 1999b, 243.

${ }^{26}$ The claim is surprising only in the context of what one might take as usual interpretations of Aristotle's moral psychology, specifically his theory of non-rational desires. There is nothing surprising in general about the claim that one can be, for example, passionate about certain intellectual activities (e.g. mathematics). 
rational desires and feelings to deliberation while the intrinsic feature to which one becomes attached is the correctness of the deliberative process. As I argue, this habitual state lies at the core of Aristotle's conception of virtue of character. Moreover, it also explains the propensity of the virtuous person's non-rational desires and feelings to follow (or adjust themselves according to) one's practical reasoning and decisions, as those specify things or actions to be done or desired. In sum: in the case of the virtuous agent, the exercise of the non-rational part of the soul is centrally focused on deliberation and decision, achieving a special kind of inner harmony between reason and non-rational desires. This is the central, unifying task or feature of virtue of character and, as I would like to argue in addition, the reason why Aristotle defines it as hexis prohairetike. It is the state of the non-rational aspect of the soul in which one is so disposed that one habitually enjoys deliberating and making and executing one's decisions.

The Virtuous Person as a Self-Lover

In $N E$ 9.8, Aristotle raises the question of "whether one should love most of all oneself or someone else' (1168a29-30). The question arises from a tension between the view that being a self-lover (philautos) is reproachable and the implications of the view, argued for in NE 9.4, that one's relation to oneself has some of the same features as friendship (philia). As is well-known, Aristotle goes on to conclude that the virtuous person is indeed a self-lover (1169a3) but of a very different kind than the reproachable and vulgar type of self-lover. ${ }^{27}$ The vulgar self-lover awards himself "the biggest share in money, honors and bodily pleasures' (1168b16-7) in order to satisfy and please

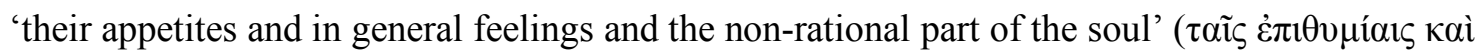

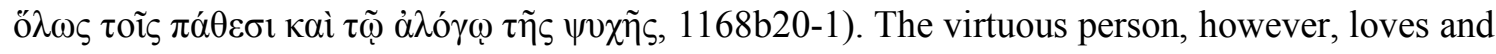

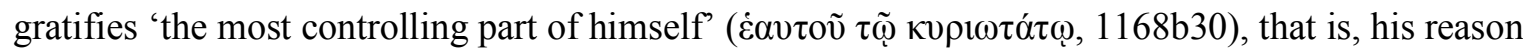

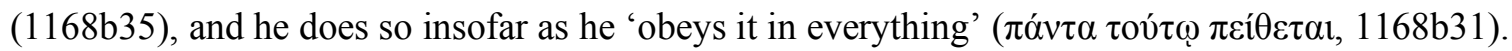
Scholars often concentrate on Aristotle's claim that the virtuous person, as a self-lover of the kind just described, is a lover of the fine since she awards herself what is fine through performing virtuous actions (1168b26-7). However, at the basis of Aristotle's claim in the chapter is not so much the fact that the virtuous person loves fine actions or fine characters but that she loves her reason (i.e. the rational part of her soul) and satisfies it by listening or obeying it (peithetai) as her master (1168b34-5). The language that Aristotle uses in making these claims is quite obviously reminiscent of the language by which he introduces the division of the soul into the rational and the

${ }^{27}$ See Annas 1993, 262 on the oddity of Aristotle's assertion that a virtuous person is a philautos. 
non-rational part in NE 1.13 (NE 1.13, 1102a28), EE 2.1 (1220a8-11) and Pol. 7.14 (1333a16-27).

Whenever Aristotle introduces the distinction, he simultaneously insists that the virtuous disposition of character involves harmonizing the two parts under the guidance of reason insofar as the nonrational part is supposed to listen to and obeys (peithetai) the rational part or reason ( $N E 1.13$, 1102b28-1103a3). The discussion in NE 9.4 and 9.8 adds a significant detail to this picture - the non-rational part listens and obeys the rational part because the virtuous person loves her rational part (NE 9.4, 1166a9-17).

Now, as Aristotle reminds us, if there is a part of oneself that one loves, it must be the case that one loves that part in virtue of some other part of oneself $(E E 7.6,1240 \mathrm{a} 13-20)$ :

(A) This [i.e. self-love] is a friendship in a way by analogy, but not without qualification. For

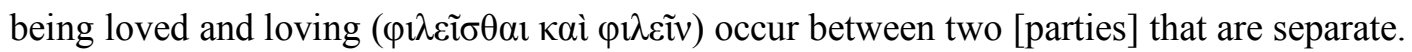
That is why one is friend to oneself more in the way in which we have said how the uncontrolled and the self-controlled person [act] voluntarily and involuntarily by having the

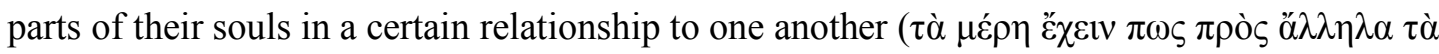
$\tau \tilde{\eta} \varsigma$ $v \chi \tilde{\eta} \varsigma)$. And in this way similarly in all such cases, whether someone is a friend or an enemy to himself and whether someone commits injustice against himself. For all these occur between two [parties] that are separate.

Since Aristotle has, for the purposes of ethical inquiry, distinguished two parts of the soul, it follows that the part that is responsible for one's love of the rational part is the non-rational part, the seat of non-rational desires and feelings. However, as passage A makes clear, one should not conceive of the non-rational part (as opposed to the agent herself) as developing an actual philia for the rational part. It would commit one to conceiving of the non-rational part (rather than of the agent) as the proper subject of emotions which is something that Aristotle sensibly warns us against (e.g. EE 2.8, 1224b24-9). Moreover, since philia essentially involves a rational desire, namely wishing the friend good for her own sake (e.g. NE 8.2, 1155b32-1156a5), it would also commit one to ascribing such a wish to the non-rational part. Rather, the idea is that the two parts stand in a certain relation to each other such that that relation enables us to speak (by analogy) of one part loving the other.

Since the non-rational part is primarily a seat of desires whose ultimate object is, in one way or another, pleasure, it can stand in the right relation to the rational part if and only if one finds the activity or activities of the rational part appropriately pleasant. As Aristotle asserts that human 
appetitive desires take as their objects anything that one finds pleasant (Rhet. 1380a18-27), it would also seem that, if one finds good or correct reasoning, deliberation, contemplation, learning or inquiry pleasant (or, for spirit, pleasant in terms of promoting or fulfilling one's self-esteem, worth or pride), one will have an appetitive desire for them. And Aristotle does in fact extend the range of appetitive desires beyond food, drink and sex. There are appetites for wealth, profit, victory or honor (NE 7.4, 1148a22-b4); intellectual contests and forensic debates (Rhet. 1.11, 1371a1-10); learning (NE 3.1, 1111a31, Rhet. 1.11, 1371a30); and even for geometry, music, arguments, writing and rational calculation (NE $10.51175 \mathrm{a} 33-\mathrm{b} 29){ }^{28}$

In the next section, I will ask how Aristotle can think that rational activities can become attractive to non-rational desires. For the moment, I want to note that Aristotle identifies the self that one loves with the part responsible for practical thinking. When in NE 9.4 Aristotle talks about the thinking part (the one that phronei) which is 'what each of us seems to be', he is talking about a part that is in agreement with the non-rational part about what to pursue (1166a12-17). And that means that Aristotle must be talking about that aspect or part of the rational part that is concerned with what is good or bad - that is, the part whose virtue is practical wisdom (NE 6.1 and 6.5). ${ }^{29}$ The identification of the rational part with the seat of practical thinking is in fact already present in Aristotle's distinction between two parts of the soul in NE 1.13. This aspect of the distinction is often missed since commentators tend to focus on the differences between the cognitive abilities of the two parts. But it is notable that Aristotle does not draw the distinction between the two parts in terms of their ability to manipulate concepts or experience feelings. Rather, he draws it in terms of the correlated powers of giving commands and listening and obeying (or being in a way persuaded by) those commands. The rational part is by nature such as to command and the non-rational part such as to obey (EE 2.1, 1220a11), that is, to follow reason (akolouthein tōi logōi) (e.g. NE 1.13, 1102b29-1103a1; EE 2.2, 1220b5-7). This means, among other things, that the rational part as distinguished in $N E 1.13$ either does not contain theoretical reason or, at the very least, is not to be thought of as reason in its theoretical aspect since ( $D A 432 \mathrm{~b} 27-3 \mathrm{a} 1)$ :

${ }^{28}$ One might object that the examples from $N E 10.5$ are of rational pleasures that are objects of rational desire (i.e. wish). However, Aristotle also talks of finding these activities painful (1175b17$19)$ and so in a way that is not related to rational aversion. Moreover, he goes on to mention appetite for praiseworthy things (1175b29) as relevant to the discussion.

${ }^{29}$ This is correctly noticed by Annas 1993, 256. 
(B) Contemplative reason contemplates nothing practical (oủ $\theta \dot{\varepsilon} v \theta \varepsilon \omega \rho \varepsilon \tilde{\imath} \pi \rho \alpha \kappa \tau o ́ v)$, and says nothing about what is to be avoided and pursued, but movement always belongs to the one who is avoiding or pursuing something. But when it contemplates something of the sort, it

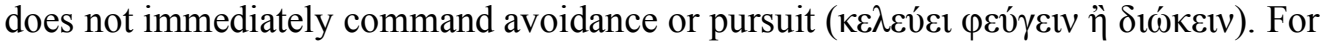
example, it often thinks ( $\delta 1 \alpha v o \varepsilon i \tau \alpha \iota)$ something scary or pleasant, but it does not command being scared, even if the heart, or if the object is pleasant some other part, is moved.

In sum, the rational activity or activities that the non-rational part, insofar as it can become or is virtuous, is supposed to find attractive (or, put more carefully, the activities that a virtuous person insofar as he has a virtuous character is supposed to find pleasant) are not just any intellectual activities but specifically those of practical reason, that is, of deliberating and making decisions. ${ }^{30}$ We will return to this idea; but before we can do so there is an immediate worry to be addressed.

\section{Non-rational Attachment to Reason and its Activities}

Since finding something pleasant is a necessary condition for forming a non-rational desire for it, one might wonder how we can find intellectual activities pleasant. An initial answer is straightforward. In order for us to find intellectual activities pleasant (i.e. to develop a taste for them), we need to develop the capacities for such activities in such a way that their exercise becomes 'second nature' to us: we have to become good or excellent at those activities. As Aristotle would say, we need to develop the capacity so that it is in the best condition and exercise it appropriately (NE 10.4, 1174b15-24). Hence, developing an appetite for intellectual activities would consist in nothing else than the proper development of those very activities. There is no other trick in developing a taste or liking for reasoning, deliberation, or inquiry than simply developing one's capacities for those very activities.

Although at a certain level of generality this answer might be true, one might still wonder how it is possible for non-rational desires that are based on perceptual (including phantasia-based) pleasure and pain (e.g. $D A 3.7,431 \mathrm{a} 8-16)$ to take as their objects rational activities, in particular practical reasoning or deliberation. One might agree that the exercise of an appropriately developed capacity for practical thinking (or even reasoning in general) is pleasant to the agent and yet deny that such pleasure is of the right sort to be attractive to (and so become an object of) non-rational

${ }^{30}$ This does not mean that (love of) contemplation and theoretical reasoning and knowledge plays no role in a good life. But it does mean that such love, as crucial as it might be for a life of eudaimonia, is not part of one's virtue of character. 
desires, be it appetite or spirit. In particular, one might think that the pleasure in question is not perceptual but rational pleasure, one endemic to the activities of thought themselves, whether it be understanding or contemplating (e.g. $N E$ 10.5, 11176a3; 10.7, 1177a22-7). Hence, despite occasional slips in terminology (e.g. epithumia for learning at $N E 3.1,1111 \mathrm{a} 31$ ) on Aristotle's part, intellectual activities are not objects of non-rational desires. ${ }^{31}$

The objection generates two closely-related questions. If it is an essential feature of deliberation and decision-making that they involve the grasp of reasons ( $E E$ 2.10, 1227a6-30), then how can they be experienced as pleasant in a way that is relevant to non-rational desires that are by definition incapable of such grasp? In a similar way, how can the non-rational part (and so nonrational desires) find particular commands or plans of reason pleasant or attractive and do so simply on the basis of the authority of reason (i.e. intrinsically) when this means that it is so attracted to something whose purpose is beyond its comprehension, issued to it for reasons that have in principle nothing to do with pleasure and pain (but rather with goodness)?

The first task is to look for independent evidence (that is, evidence other than the passages concerning virtue of character that are under investigation) that Aristotle recognizes non-rational, pleasure-based, habitual attachment to intellectual activities. We can distinguish two different ways in which such attachment can obtain. On the one hand, reasoning can be something that one likes to do not so much because one finds it pleasant as such, but on account of external rewards or because of some feature that is accidental to it. On the other hand, one can find it pleasant and rewarding to engage in reasoning as such, that is, intrinsically. I discuss these two ways under the headings of extrinsically and intrinsically motivated kinds of non-rational attachment, arguing that Aristotle recognizes them both.

${ }^{31}$ In addressing this worry, one might be tempted to appeal to Aristotle's assertion that human thinking requires phantasia (DA 3.7, 431a14-17, DM 449b31-450a1) and try to offer a phantasiabased account of the way in which one can come to have a non-rational desire for thinking. However, phantasia, as Aristotle describes it, is dependent on previous perception. Consequently, we can only have phantasiai of things we have previously perceived or, at any rate, only phantasiai that are ultimately derived from such perceptions ( $D A 3.3,428 \mathrm{~b} 10-429 \mathrm{a} 2)$. Since it is not obvious that Aristotle thinks that we can perceive thinking (as opposed to being aware of our thinking in or by thinking itself - see Caston 2002, 774-5), it is also not obvious that we can even have phantasia of thinking (as opposed to phantasiai of the things about which we are thinking). But, even assuming that we could overcome this obstacle (say, by arguing that the common element of memories of many different episodes of thinking just is the experience of thinking itself, or by exploring the kind of phantasiai that we have when we think about thinking), it is unclear whether such an account would provide any useful illumination of the problem at hand. The problem is not so much how thinking can be perceptually represented but, rather, how the non-rational part can be attracted to something (i.e. thinking) that by its very being transcends its comprehension. 


\section{Extrinsically Motivated Attachment}

One can become attached to an activity even if the activity as such (or itself) is not what motivates the attachment. A particularly well-known form of developing an attachment of this sort (and one often emphasized by scholars of Aristotle's ethics) concerns children who can become attached to certain routines through external rewards or deterrents (such as praise and blame). However, for our purposes a more interesting form is one in which the attachment is motivated by a feature (or features) of the activity itself but the feature is something that one finds attractive independently of the activity. For example, one can find it pleasant and satisfying to accomplish a difficult task or achieve a difficult goal and so undertake various tasks precisely because they are challenging and difficult. One can thus be fully committed to climbing a mountain or solving a mathematical problem, even if it is not the problem or the mountain as such but the challenge of solving the problem or climbing the mountain that motivates one's efforts. ${ }^{32}$

Aristotle recognizes non-rational attachments of this sort, and it is not difficult to extend their range to intellectual activities. In Rhet. 1.11, he tells us that people take pleasure in and so find desirable (epithumetton) what they admire (1371a23). What is admired is, in turn, something that is impressive, difficult and so deserving of praise. ${ }^{33}$ Later, in Rhet. 2.11, Aristotle describes an emotion that is felt when one does not have (but is, at least in principle, able to acquire) something worthy of honor and admiration: zēlos (emulation). ${ }^{34}$ Unlike envy (phthonos), which is an ethically undesirable emotion, emulation is a positive emotion: not only it is directed at achieving good and useful things (such as courage or wisdom: 1388b16), but it also (and unlike envy) does not imply

32 This kind of emotional attachment occurs in playing games, be it sport or board games. Games usually have goals that are trivial or meaningless outside of the game (such as collecting all cards of a certain sort, or reaching a certain place on a game-board). The goals are also often such that one could reach them effortlessly if one were not playing the game (for example, in Monopoly, one could just hold the property cards in one's hand). But games have rules that are meant to make reaching the goal challenging and, thus, attractive: in playing games we enjoy the challenging form of the pursuit of the goal rather than the goal itself. Yet, we are at the same time emotionally committed to reaching the goal - after all, we are disappointed if we fail and rejoice if we succeed.

${ }^{33}$ For a discussion of the connection between admiration and impressiveness or difficulty, see Warren 2014, 69-71.

${ }^{34}$ Cooper's gloss of zélos as 'feeling eagerness to match the accomplishments of others' in Cooper $1999 c$ is helpful but difficult to use as a translation. For a discussion of the problems of translating zèlos see Rapp 2002, 674-5. 
wishing ill to one's rivals (1381b21-3). ${ }^{35}$ Now one of the things that is praised and admired is reason, ${ }^{36}$ and so it does not seem unreasonable to conjecture that the ability to deliberate well, something for which, say, Pericles became famous (e.g. $N E$ 6.5, 1140b5-8), is admired and held in high esteem, and so invites emulation. ${ }^{37}$

For our purposes, the most interesting example of an extrinsically motivated attachment of this sort is the stubborn person whom Aristotle calls idiognōmōn. This kind of stubborn person is non-rationally attached to her beliefs because they are her beliefs. As Aristotle notes, the idiognomōn is similar to the self-controlled person in the same way in which the wasteful person is similar to the generous one. It will be useful to explore the analogy. The wasteful person has features proper to the generous person since she gives and does not take (NE 4.1, 1121a21-2). Her character, as Aristotle notes, is more foolish than vicious (1121a25) since she gives (as the generous person does) but does not give to the right people and she might even be taking from the wrong sources. She is thus benefitting others but might not be benefitting the right people and might even be harming herself in the process. Although there is something right about the basic orientation of her feelings (towards benefitting others), there is still more work for both proper habituation and learning (1121a23-4). Accordingly, then, the idiognōmōn is already doing something she is supposed to: just like the self-controlled person, she is sticking to her beliefs. But while the selfcontrolled person holds on to them because she is rationally persuaded about their truth, the idiognōmōn does so 'on account of feeling and appetite' (NE 7.9, 1151b7-12), that is, because she finds it pleasant to stick to her beliefs insofar as they are hers. Consequently, she might not be sticking to the right views (at the right time, etc.). She needs further habituation that would transform her attachment from one based on the fact that they are her views to one based on the value or truth of those views. ${ }^{38}$ This is a crucial clue in our search for the essential element of virtue of character, one that we will explore in the next section.

${ }^{35}$ On this point, see Viano 2002, 245.

${ }^{36} N E$ 1.13, 1102b14; cf. Rhet 1.11, 1371a31-3: 'learning and wondering at something are for the most part pleasant. For in admiring there is an appetite (epithumein) to learn so that that which is wondered at is also what one has an appetite for (to thaumaston epithumēton).'

${ }^{37}$ This would be particularly so for young people who, as Aristotle tells us in Rhet. 2.12, 1389b30-5 are epithumetikoi and thumikoi, that is, full of appetites for superiority and of spirited desires to match the accomplishment of others and distinguish themselves so as to earn praise and honor.

${ }^{38}$ It should be noted that, even in a mature life, there is a legitimate space for attachment to things on the basis of the fact that they are the results of one's own efforts. For example, Gaia wishes to promote her health by healthy eating. Upon deliberation, she realizes that the best thing for her to 


\section{Intrinsically Motivated Attachment}

The virtuous person's non-rational attachment to her own reason and intellectual activities cannot be motivated merely extrinsically. The self-controlled person and so also the virtuous person is supposed to stick to her beliefs because they are true, not merely because they are hers. Moreover, the virtuous person's attachment to her reason and intellectual activities must be lasting and firm and there would be no guarantee that it would be such if it were based on extrinsic features. One could always find something else that would have those features - even the stubborn person can change her views when it pleases her while remaining obstinate about whatever views she currently holds.

The idea of intrinsically motivated attachment is not difficult to grasp - one can find it attractive or fun to do things precisely because one enjoys doing that kind of thing. But one might wonder what it is about intellectual activities, as such, that one can find non-rationally attractive. In the case of extrinsically motivated attachment, the attachment was mediated by a feature to which non-rational desires were already (non-problematically) assumed to be sensitive (such as presenting a challenge, fulfilling a sense of pride or accomplishment, or being of the product of one's own efforts). The problem is that, in the case of intrinsically motivated (non-rational) attachment, the features that we are interested in (such as truth, coherence or intelligibility) seem to transcend the cognitive capacities of the non-rational part. They do not seem to be of the right sort to be (unproblematically) assumed to motivate a non-rational attachment.

In order to tackle the problem, it will be useful to distinguish two different ways in which one can find intellectual activities satisfying. On the one hand, one can derive satisfaction from (reaching or obtaining) understanding (i.e. from grasping the proper explanation) of something that one is thinking or inquiring about. This kind of satisfaction is a rational matter and one for which Aristotle attributes to human beings an inborn impulse or desire. ${ }^{39}$ In fact, understanding (as provided by knowledge) is nothing other than the very object of reasoning - it is the particular form

do is to cook three healthy meals on Sunday that she will then eat during the week when she has no time to cook. Before she deliberated she had no desire to cook three meals on Sunday. But now she finds the plan exciting - after all, she just spent considerable amount of time figuring it out! It is her plan and decision, and she would be sad or pained should it not work out. As Aristotle remarks: 'all people love their own works more [than other people's], just as parents and poets do' (NE 4.1, 1120b13-14).

${ }^{39}$ The locus classicus is Metaph. 980a22 but see also Poet. 1448b5-23. 
of truth that reasoning seeks (NE 6.2,1139a23-31). But although understanding, as a grasp of truth, is a rational matter, the habit of trying to understand things (or even the habit of finding oneself always being able to understand things!) need not be. As Aristotle is well aware, we can derive satisfaction from fulfilling a need for engaging in an activity of a certain sort where such need arises from having become accustomed to that activity, that is, from it having become part of our (acquired) nature to do so (e.g. Probl. 28.1, 940a29; Rhet. 1.11, 1371b20).

Aristotle talks of various things that one can become accustomed to in this way, ${ }^{40}$ but for our purposes the question is whether he thinks that there can be a felt need (i.e. a non-rational desire or feeling) to think or deliberate that is motivated by one's liking or love of (features intrinsic to) good thinking or deliberating (such as correctness, truth or coherence). There are a number of passages in which Aristotle talks about finding intellectual activities pleasant or painful, such as geometry, or rational calculation (e.g. $N E 10.51175 \mathrm{a} 33-\mathrm{b} 20)$ and we are even told that one of the virtuous person's non-rational states $(N E)$ or affections $(E E)$ qualifies her as a lover of truth (philalèthēs) (NE 1127b4; EE 1234a3). ${ }^{41}$ But perhaps the most explicit statement of a habit directed at features of thought is in the following passage (Metaph. 2.3, 994b32-995a14, tr. Reeve, slightly modified):

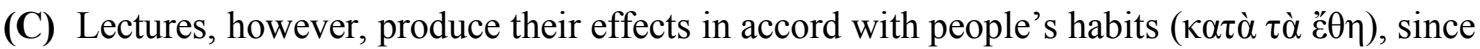

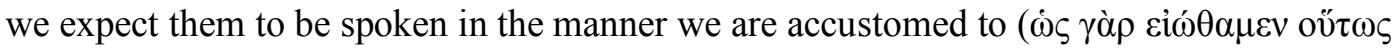
$\hat{\alpha} \xi 10 \tilde{v} \mu \varepsilon v)$, and anything beyond this appears not to have the same strength but to be

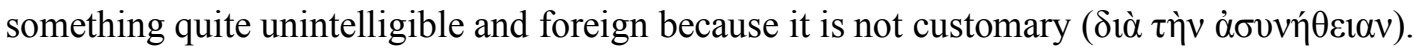

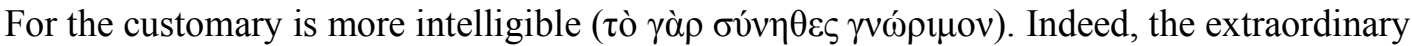
power of what we are accustomed to is clearly shown in our customs, where mythical and childish stories about things have greater power than our knowledge about them, because of

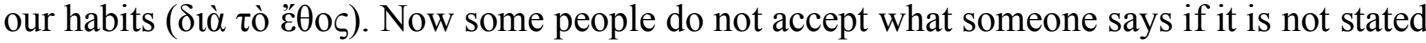
mathematically, others if it is not based on paradigm cases, while others expect to have a poet adduced as a witness. Again, some want everything expressed exactly, whereas others are pained by what is exact, either because they cannot string together all the bits together or because they regard it as nitpicking. For exactness does have something of this quality, and

\footnotetext{
${ }^{40}$ For example, melodies (Probl. 920b29-921a7).
}

${ }^{41}$ Some dispositions of the non-rational part of the soul are not recognized as virtues in the $E E$ since they are 'without decision' (1234a26), but are recognized as such in the $N E$. 
so just as in business transactions so also in arguments, it seems to have something unfree or ungenerous about it. That is why we should already have been well trained in what way to accept each argument, since it is absurd to look for scientific knowledge and for the way [of inquiry] characteristic of scientific knowledge at the same time - and it is not easy to get hold of either.

As this passage makes clear, we can become so accustomed to speeches or lectures having a certain form or character (be they passionate pieces of oratory or scientific expositions) that when they do not conform to that form, we find them painful to listen to. The painfulness in question is not merely rational dissatisfaction since it can stem from our finding the speech boring and annoying (say, because it is nitpicking) even if we deem it true and well-reasoned. Even more importantly, we can experience the same feelings (i.e. have painful or pleasant reactions) in relation to rational features of a speech, such as its intelligibility. We can find it painful and annoying if we cannot 'string together' the argument - that is, we can experience pain when our habit of being able to understand things is frustrated (i.e. if we cannot figure out the argument or perhaps if we find the lecture lacking one). It is worth noticing that it is also out of habit that we try to 'string together' the argument. Others whose habits differ from ours might not feel any need to do so. The general lesson of passage $\mathrm{C}$ is that we can form non-rational habits concerning intrinsic features of thought or reasoning, such as truthfulness or logical coherence. Consequently, we can find it enjoyable to attend to, or to execute well-constructed or true thought or reasoning, or painful to attend to or to execute one that fails to be such.

Further evidence for the claim that one can develop a non-rational attachment to features intrinsic to rational activities or states can be adduced from the following passage (NE 7.9, 1151b17-22):

(D) Then there are also some people who are prone to not stick to their beliefs but not because of

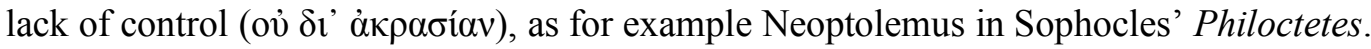
Although it was because of pleasure that he did not stick [to his beliefs], it was a noble pleasure ( $\dot{\alpha} \lambda \lambda \dot{\alpha} \kappa \alpha \lambda \eta \dot{v})$. For telling truth was pleasant ${ }^{42}$ to him but he was persuaded by

${ }^{42}$ I follow Ramsauer's conjecture (along with, for example, Gauthier-Jolif, Irwin or Reeve) reading $h \bar{e} d u$ instead of the mss.' kalon. Ramsauer refers the conjecture to Philoct. 900-10, where Neoptolemus talks about how painful and torturous for him telling lies is. But there are at least two other reasons for it, given in the passage. First, if telling truth was a noble thing for him, as the 
Odysseus to lie. For not everyone who does something because of pleasure is either selfindulgent, base, or uncontrolled, but only one who does so because of shameful pleasure ( $\dot{\alpha} \lambda \lambda^{\prime}$ ò $\left.\delta \imath^{\prime} \alpha i \sigma \chi \rho \alpha ́ v\right)$.

Neoptolemus is persuaded to lie by Odysseus and promises to do so but later, on account of his love of truth (which comes from his finding telling truth pleasant), he does not abide by the promise ( $N E$ 7.2, 1146a17-22). Although in $N E 7.9$ Neoptolemus is introduced as someone who is not acting from (unqualified) lack of control, he is nevertheless like someone acting in that way since he abandons his decision on account of pleasure: 'he is already persuaded, yet nonetheless does something else' ( $N E$ 7.2, 1146b1-2), just like the uncontrolled person. In $N E$ 7.2, Neoptolemus is thus introduced as someone who acts with 'a sort of excellent' (1146a19) lack of control: he abandons his decision but his action is praiseworthy since the pleasure (as in NE 7.9) or pain (as in $N E$ 7.2) that made him not stick to the decision is noble. In sum, despite his (rational) decision to act in a certain way, his non-rational part, on account of its strong attachment to truth, leads him to abandon and act against it. ${ }^{43}$

reading of the mss. would have it, Neoptolemus should not have been persuaded to act otherwise in the first place. Second, the sentence is supposed to further explain why he did not stick to his promise - it is indicated in the previous sentence that it was on account of pleasure, and this sentence tells us what the pleasant thing was.

${ }^{43}$ Cagnoli Fiecconi 2018 argues that, in breaking his promise to Odysseus, Neoptolemus is acting on a rational desire (i.e. a wish) 'to appear praiseworthy' (248) which, in a given situation, includes or implies a wish to tell the truth. She argues that Neoptolemus' choice to lie is not a decision (i.e. a prohairesis) since his 'choice to lie frustrates his own ends and is against the grain of his character' (249). She concludes that in telling the truth Neoptolemus is acting 'in accordance with a prohairesis' since his action 'is in accordance with his commitment to abide by his conception of the goal' (249). If her interpretation is correct, Neoptolemus' action is nothing like an action of the uncontrolled person. Several points seem to me decisive against her interpretation. First, Neoptolemus is introduced as an example of those who, on account of pleasure, do not abide by

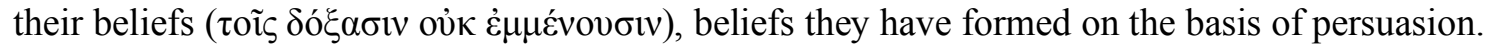
This is a standard way of describing uncontrolled action. The self-controlled people are those who

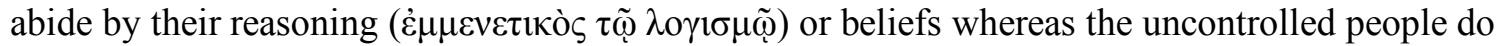
not (NE 7.1, 1145b10-11; 7.2, 1146a16-17). In fact, the whole discussion in NE 7.3 is cast as a discussion of how the uncontrolled agent comes to abandon, on account of pleasure, her knowledge or belief when she is firmly persuaded about that belief(1146b24-31). Aristotle never revises or denies the description of Neoptolemus along these lines. Second, Neoptolemus' choice to lie is done on the basis of thinking about how to obtain something he wishes for, namely profit. According to $N E$ 3.3, a choice of this sort is a decision. Cagnoli Fiecconi maintains that decisions must reflect the agent's character and so also their overall conception of the good life. But even if true, this additional requirement does not help. If Neoptolemus was attracted to profit, then love of profit must have been part of his character and profit one of his ends. Thus one cannot deny that his 
For our purposes, two points stand out. First, Neoptolemus' love of truth is non-rational despite the fact that truth is a rational feature that pertains to thoughts or beliefs (e.g. Metaph. 1027b25-7). That such attachment to truth should exist is not surprising. Honesty might well be a certain kind of attachment to truth which involves strong aversion to lying, but it does not imply attachment to truth understood as love of knowledge and, correspondingly, aversion to ignorance. ${ }^{44}$ Second, his love of truth makes him find it painful to tell lies even as he is made to see the usefulness of telling the lie. In other words, his knowledge that what he would say is false makes the act (non-rationally) painful to him. We are now in a position to tackle the main questions of the paper: the nature of reason's influence on non-rational desires and the definition of virtue of character.

\section{Virtue as Attachment to Deliberation and Decision-Making}

I have argued that, on Aristotle's view, the virtuous person is a specific kind of self-lover, namely one in whom the non-rational part finds pleasant or otherwise appropriately desirable (the activities of) the rational part. I have also argued that Aristotle thinks that non-rational desires can take as

choice to pursue it is a decision on the ground that 'it frustrates his own ends and is against the grain of his character'. That his desire for profit comes into conflict with his other goals or commitments is a consequence of his lack of virtue (or lack of consistency among his own ends and values). In fact, the decision to tell the truth (a decision Cagnoli Fiecconi claims he made) would also come into conflict with some of his ends, namely with his love of profit. There is no reason to privilege love of truth over love of profit as being really part of his character (see $N E 3.1,1110 \mathrm{~b} 13-15$ ). Third, Aristotle denies that Neoptolemus' action is unqualifiedly uncontrolled because the pleasure that moves him to act as he does is fine and not, as Cagnoli Fiecconi suggests, because he acts in accordance with his prohairesis. In general, he denies that inverse akrasia (of which Neoptolemus is an example) is unqualified akrasia because the overpowering pleasure (or pain) is praiseworthy or noble, leading to a praiseworthy action. This is also how Neoptolemus is portrayed in Sophocles' play: as someone who becomes nauseated, distressed and disgusted by the shamefulness of the action he has decided to do. Cagnoli Fiecconi seems to me to go wrong in making two assumptions: (1) that the actions of inverse akratics are not comparable to virtuous actions because virtuous actions need to be 'with and not against a prohairesis' (245); and (2) that 'the majority of akratics are in a bad and blameworthy state' reflected in their decisions (ib.). Concerning (1), all Aristotle needs is that the action of the inverse akratic is praiseworthy rather than blameworthy. If the actions of unqualified akratics, which are not based on decision, can be blameworthy, then the actions of inverse akratics can be praiseworthy. Concerning (2), it depends on what is meant by 'state'. The inverse akratics are supposed to be people whose good state of character (i.e. of the non-rational part of the soul) goes against their beliefs. The decisions they make in view of those beliefs (just like the decisions of regular akratics) thus do not fully reflect their character (which is given by their non-rational desires rather than their reasoned beliefs).

${ }^{44}$ See Rep. 535e. I thank Naly Thaler for this point. 
their objects (and so become attached to, or invested in) intellectual activities or states, and that they can do so in at least two distinct ways, depending on whether the attachment is motivated by features that are extrinsic (such as difficulty or ownership) or intrinsic (such as truth or coherence) to reasoning. In the latter case, the attachment is, at least typically, developed through habituation. These claims provide the basic ingredients for the view I want to defend, namely that virtue of

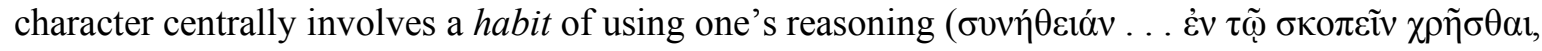
$E E$ 1248a36-7) to guide one's actions and feelings. This habitual state is manifested as a felt need or desire to subject one's non-rational desires and feelings to deliberation in which one not only finds out how to satisfy them but also evaluates their goodness and modifies them as appropriate.

To begin with, there is no shortage of passages in which Aristotle tells us that the virtuous person uses reasoning to guide her actions and her non-rational desires and feelings. In $N E$ 1.3, he contrasts the virtuous people with those who are immature or uncontrolled, telling us that knowledge and reasoning are of little use for the latter since they live in accordance with their

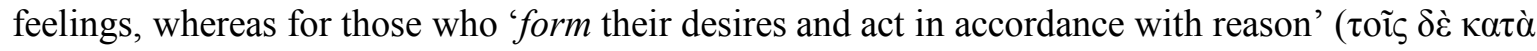

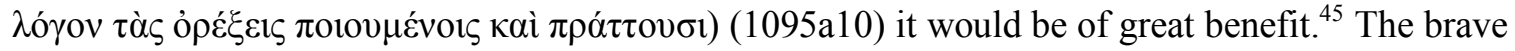
person, for example, 'acts and feels according to what things are worth and as reason [prescribes]' (NE 3.7, 1115a19-20). Perhaps most explicitly, Aristotle identifies the particular non-rational hexis that constitutes the virtue of wittiness as one that accepts or allows taking pleasure in what is humorous in accordance with reason (EE 1234a10-14). The idea of guiding one's life, including one's actions and desires, by one's reasoning is also present in the discussion of what produces eudaimonia in EE 8.2. Aristotle considers people whose desires happen to be for the right things even when their reasoning (logismos) is silly or random - they are, as he says, 'lucky contrary to all knowledge and correct reasoning' (1248a3). Such people's appetites are for the right things and at the right time and they end up being happy. Nevertheless, as he tells us, the cause of their appetites being correct is not human reasoning as it should be (1248a5-7). The obvious presupposition is that the virtuous person achieves the right desires, including non-rational desires, through the use of her (correct) reasoning.

In passages of this sort (I will attend to more below), Aristotle requires that the non-rational part of the virtuous agent accepts the guidance of reason not merely insofar as it does not resist it or

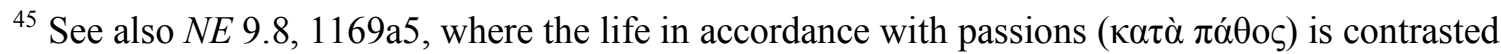

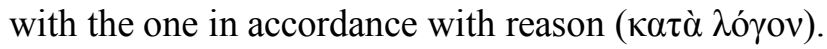


that it happens to always already desire what reason commands, but also insofar as it adjusts itself according to reason's guidance. As he says (NE 3.12, 1119b12-17):

(E) Just like the child must live by the commands of the guide, so also the appetitive part [must live] according to reason. Hence, the appetitive part of the temperate person must speak in harmony with reason: for the goal is the fine for both, and the temperate person appetite is for the right things, in the right ways and at the right times, just in the way as also reason commands.

In order to see the full force of this passage, it will be useful to bring out the various ways in which Aristotle thinks the non-rational part of the virtuous agent is supposed to follow and live in accordance with reason. It is crucial to recognize that the commands or prescriptions of reason that the non-rational part is supposed to follow are not constrained to those issued on and for particular occasions. Although there is little doubt that such commands are among those that Aristotle has in mind (say, decisions to act or refrain from acting in some particular instance), there is also little doubt that reason issues more general commands, rules, plans and schemes as well and that Aristotle thinks that the non-rational part is supposed to follow or obey reason with respect to those too.

At the end of $N E 3.11$, Aristotle tells us that the temperate person adjusts her appetites according to the considerations of health, bodily fitness, financial means and fineness (1119a11-20):

(F) The temperate person is in an intermediate state concerning these [bodily pleasures]. For he does not find pleasure at all in those things that the intemperate person finds most pleasure in, but is displeased by them, nor does he find pleasure at all in things that one shouldn't, nor extreme pleasure in anything of such a kind, nor does he feel pain or appetite when such things are absent, or only moderately so, not more than one should, and not when one shouldn't, nor in general anything of that sort. But those pleasant things that are conducive to health and fitness, he will desire moderately and in the right way, as he will also other pleasures if they are not obstacles to these [health and fitness], or are not contrary to the fine, or are not beyond his means. For one who is in that condition [i.e. of desiring these pleasures without regard to these considerations] likes such pleasures more than they are worth. But the temperate person is not of this sort, but [he likes them] in the way correct reason prescribes. 
As Aristotle clearly implies in the passage, the thought of something being unhealthy or beyond one's means has direct consequences for the virtuous person's appetites - if she finds something to be of that sort, she will either not form an appetite for it or, should she have already formed one, she will lose it (or perhaps even turn it into an aversion). It is noteworthy that this is not a case of reason influencing appetite by presenting to it something else to desire or be averse to, painting, as it were, a pleasant or painful image to divert its attention. ${ }^{46}$ Although this is, no doubt, one way in which people try to curb their appetites, the case of the virtuous person highlighted here is different: the very thought of something being unhealthy or beyond her means causes her appetites to react appropriately. As the case of the temperate person illustrates, her adoption of a rule to lead a healthy lifestyle governs not only her actions but also her appetitive desires. ${ }^{47}$

A different way in which non-rational desires are supposed to follow reason can be found in Aristotle's account of the generous person. The generous person acquires wealth only as a means to an end and does so only from the right sources. She makes sure that her possessions are well taken care of but only because she always keeps in mind that she will want to assist others in need when that becomes appropriate and fine (NE 4.1,1120a24-1120b4). The generous person thus undoubtedly has to engage in careful thinking and planning and her relevant desires need to adjust and follow those plans. ${ }^{48}$ For example, she will not enjoy acquiring possessions apart from doing it for the right purpose and she will desire to give only when it is fine to do so as determined in each case by reason rather than just to anyone who might need or want help (NE 4.1, 1120b1-4). When the generous person forms a plan to acquire funds to support a future good cause, she need not then, on each relevant occasion, direct her non-rational desires or feelings away from giving when doing so would not be in accordance with her plans. As Aristotle portrays it, the adjustment happens in a much more integrated way. The case of the generous person, then, highlights the ability of the nonrational part to follow reason as it plans, deliberates and shapes one's values and goals.

There is, then, no doubt that the virtuous person's non-rational desires and feelings follow reasoning in the sense of adjusting in accordance with reason's prescriptions and plans. When the virtuous person is prompted to act by her non-rational desires, she employs, whenever appropriate,

${ }^{46}$ Cf. Lorenz 2006, 195 (quoted in n. 25 above).

${ }^{47}$ The same points could be extracted also from $E E 2.5,1222 \mathrm{a} 29-34$ or $N E 4.6,1126 \mathrm{~b} 28-1127 \mathrm{a} 6$.

${ }^{48}$ Since generosity is concerned with wealth, and generous actions are supposed to be pleasant (or at least painless), the desires involved in generous actions must include appetitive desires either as supporting or carrying out one's actions or, at the very least, as not opposing them ( $N E 2.1$, 1120a24-8). 
her reasoning not only to find out how to satisfy them but also, and more importantly, to evaluate them in view of her relevant knowledge and values and, if needed, adjust, redirect or otherwise modify them. Moreover, as the collected evidence clearly shows, the non-rational desires of the virtuous agent are supposed to respond to reason directly, listening to or obeying it simply in virtue of its authority. The evidence also gives us a clue about how this is possible. The various ways in which the non-rational part of the virtuous agent follows and adjusts itself according to reason highlight a feature that Aristotle already stressed in $N E$ 1.13, namely that the non-rational part of the soul is characterized in terms of its ability or capacity for what we might, collectively, call rulefollowing. 49

If the non-rational part is primarily the seat of non-rational desires and feelings (that is, the psychic center of our pleasant and painful experiences), then its description as being naturally such as to follow the commands, rules and prescriptions of reason suggests that the virtuous agent experiences as pleasant and attractive the very activity of following the rules or commands of reason. The correct sense of 'naturally' is crucial here. When, Aristotle tells us (either in NE 1.13 or $E E 2.1)$ that the non-rational or desiderative part of the human soul is such as to listen to and obey reason 'by nature', he does not mean that it is such from its inception. Since Aristotle maintains that children and young people live according to their feelings, having reason only in an immature way, it would be odd to expect the non-rational part to be capable of being obedient to reason in the relevant sense right from the birth. In fact, the different degrees in which the non-rational part is responsive to reason in the virtuous, self-controlled or uncontrolled agent (NE 1.13, 1102b26-8) suggest that responsiveness to reason, being an essential feature of virtue, is developed by habit (just like virtue). Hence, when Aristotle tells us that the non-rational part is such as to obey and listen to reason 'by nature', the sense of 'by nature' is the one explained at the beginning of $N E 2$ : human beings have a natural capacity to acquire the propensity to obey reason and this capacity is

${ }^{49}$ If this is a correct general characterization of the non-rational part, then it is not surprising that Aristotle describes it as both 'in a way' rational and non-rational (NE 1.13, 1103a1-2). Following rules is rational since it requires intentionality, grasp of language or the ability to see that one has not followed a rule. For example, children are capable of following rules (say, of a game) and in order to do that they need to understand both the goal and the rules and be able to use them to form a plan about how to achieve the goal. This involves the ability to tell whether an instance of play is a valid application of the rules and the ability to correct themselves. But following rules can also be non-rational in the sense that it does not require that one understands why the rules should be followed or why it would make sense to follow them (rather than some other rules) or whether there are any reasons (over and above the immediate goal of the game or the fact that one has fun doing so) to follow them. In a similar vein, when a child is instructed to behave appropriately, the child can do so without having any understanding of why behaving so is good and appropriate. 
completed or perfected through habituation (NE 2.1, 1102b25-6). The non-rational part can (and should) develop in such a way that it will find it natural and pleasant to follow the commands or rules of reason as reason issues them.

The claim is, then, that insofar as the formation of non-rational desires is concerned, the virtuous agent has a standing concern or a habitual need and desire to subject those very desires to rational examination and deliberation. Following Aristotle's dictum that we become virtuous by doing virtuous action (NE 2.2, 1104a20-b4), the establishment of this standing concern or habitual need should follow familiar route: it is developed through engaging in deliberation about one's nonrational desires and through acting on such deliberation. Presumably, at first it would be parents or teachers showing the young adult how to think about what to do, ${ }^{50}$ while later the child (or young person) would be motivated to deliberate on her own on the basis of various extrinsic features. Ultimately, she would acquire a taste and become attached to exercising her ability for such deliberation as such..$^{51}$

However, insofar as the development of virtue is concerned, the agent also needs to 'persuade' (or, rather, imprint on) the non-rational part of her soul that it is desirable and pleasant that it be guided by true reasoning. Her deliberative efforts thus must: (a) prove to be correct insofar as acting in accordance with them results in a satisfying resolution of the desire or feeling (or, alternatively, not acting in accordance with them results in the desire or feeling being frustrated); (b) be based on assessing the goodness (or appropriateness) of one's non-rational desires or feelings rather than consist in mere figuring out a way of satisfying them. Aristotle thinks that (a) and (b) go hand in hand: our non-rational desires can find true satisfaction only if we base their satisfaction on

${ }^{50}$ One should not conceive of this stage in terms that are too narrow. Although the evidence from Politics 7 and 8 is incomplete, it is clear that Aristotle thinks that there are activities that are to be pursued in youth (such as games or music) which develop not only one's ability to engage in intellectual activities later in life (Pol. 7.17, 1336a24-30; 8.3, 1338a25-31) but have a formative effect on one's non-rational nature, including one's disposition for obeying or following reason. Undoubtedly, he is following Plato in this regard. In the Republic (424d-425a; 558b), Plato tells us that the games that children play need to be well-governed by laws and rules since by playing games like this (along with listening to the right music, poetry etc.) they develop into the right sort of persons. Similarly, in the Laws, he insists on the importance of the appropriate selection of games as means to prepare for the activities that one will have to do in adult life - to develop both the required skills and also the liking for those activities (Laws 643c; 797a).

${ }^{51}$ I should emphasize that my concern lies primarily in what (and on what basis) Aristotle thinks we can get habituated to rather than in the precise nature of the process of habituation and virtueacquisition and the transitions between its different stages. On those issues, see the different accounts in Burnyeat 1980; Curzer 2002; Lawrence 2011. 
considerations of (true) goodness. Otherwise, the built-in tendency of non-rational desires for excess will result not only in unhealthy (or bad) living but also, ultimately, in a permanent condition of dissatisfaction. As Aristotle maintains, non-rational desires that are unrestrained by correct reason and understanding (and thus are allowed to attach themselves to unnecessary and excessive pleasures) become, due to their unlimited nature (Pol. 1267b1-6), insatiable (NE 3.12, 1119a35b17; 9.4, 1166b2-27; MM 1211b1-3). The life of the vicious person who at all times aims simply at satisfying her desires for pleasure, without evaluating them in terms of goodness, is thus, perhaps paradoxically, the most miserable kind of life (1166b27).

Feature (a) ensures that the agent becomes convinced that thinking or reflecting on her desires is the best way to find satisfaction, where her 'being convinced' is closely related to developing a habit of doing so - it is through repeated and accumulated experience of satisfaction that one becomes so convinced. Just as one can develop distrust of something from experience (e.g. $E E 7.2,1237 \mathrm{~b} 30$ ), one can develop a trust in it too. Of course, as Aristotle often stresses (e.g. $N E$ $2.3,1104 \mathrm{~b} 11-3)$, in order for this to work, the agent's desires must be, at least initially, independently primed for certain types of satisfaction. This does not mean that they must be so primed for all possible objects or types of pleasures. For example, children who are early on introduced to healthy types of food or to reading books, will find it easier to accept deliberation or decisions that tell them to study more or to avoid excessive consumption of sweets. In general, once they see that relying on reasoning leads to more satisfaction and better results in one area, they are more likely to rely on it in other areas too. ${ }^{52}$

Feature (b) is responsible for developing a habit which includes the want or need to determine the truth about the appropriateness or usefulness of one's desires. Since the successful realization of feature (a) has been brought about by reasoning that is correct or true, the agent is becoming habituated not merely to reasoning about her desires, but to true or correct reasoning about them. She is thus developing an attachment to truth (1234a2), specifically to truth in reasoning. ${ }^{53}$ As a result, she finds it pleasant and motivating to be guided by correct reasoning about the goodness of her desires or actions. She feels a need to deliberate about acting on her desires and enjoys not just the fulfillment of her desire, but the fact that she fulfilled it in the correct

${ }^{52}$ See NE 1.4, 1094b27-1095a11; 2.1, 1103b23-6; Pol. 71.5, 1334b6-28.

${ }^{53}$ One could here appeal to Aristotle's discussion of the unnamed virtue of truthfulness in $N E 2.7$, 1108a10-30 as offering a model of attachment to truth. Of course, in the case of this particular virtue, it is the attachment to truth about one's merits, achievements and actions when one communicates them to others. 
way in accordance with her reasoning. In different areas, this need or commitment can be characterized as commitment to temperance, courage or generosity - not because, for example, she has to tell herself to be temperate or ask herself what a temperate agent is supposed to do, ${ }^{54}$ but because having or feeling the need to ask herself whether eating something in a certain amount and on a certain occasion is appropriate, and adjusting her desires on the basis of such thinking just is what it means to behave temperately. As Aristotle says, in being temperate one does not enjoy merely abstaining (or eating the right food) but abstinence itself (or the appropriateness or healthiness of the food) (NE 2.3, 1104b5-6). Conversely, she finds it annoying or otherwise disturbing or disconcerting not to have done so (see e.g. passage $\mathrm{D}$ above).$^{55}$

On Aristotle's view, then, virtue of character is the state of the non-rational part of the soul that makes one disposed to enjoy and engage in true or correct reasoning about how to act and in which one forms non-rational attachments to the results of one's deliberative efforts, that is, one's decisions. The virtuous person is prone to making, and enjoys acting on, her thoughtful decisions about her life and actions (e.g. NE 6.5, 1140a31). This is the central task of virtue of character. I have also argued that the virtuous person experiences the pleasantness or painfulness of things or actions in direct dependence on what reason says about their correctness, usefulness, fineness or appropriateness. For example, although the sight of a nice piece of cake might be appealing to her, once reason determines it would be unhealthy to eat it, this determination is decisive for her nonrational desires too. The whole way in which she perceives the cake (in terms of how pleasant or desirable it looks) changes accordingly. It is the peculiar feature of the virtuous agent that her nonrational desires are sensitive to reason's prescriptions in this way - she perceives or experiences the world through the prism of reason (NE 6.12, 1144a29-36).

If we return to the conception of the virtuous person as a self-lover, we can see virtue of character as a state in which one loves and cares for, and so listens to, correct reason. Consequently,

${ }^{54}$ This is not an uncommon understanding of Aristotelian virtuous agent. See, for example, Gottlieb 2009, 165. It is, of course, subject to the charge of 'moral self-indulgence' (Williams 1981, 45).

55 This point has been made perhaps most notably by Myles Burnyeat $(1980,77)$ : 'the actions which the practice of the virtues requires could only be enjoyed if they are seen as noble and virtuous.' However, Burnyeat does not really provide an explanation how it is possible for the virtuous agent's non-rational enjoyment of things to depend on his rational assessment of them beyond the fact that what the virtuous person enjoys is 'the practice of the virtues undertaken for its own sake' (ib.), and that this enjoyment is the result of habituation. Even while he emphasizes that habituation involves rational components, he sees it as largely concerned with finding enjoyment in external things and with learning the proper conceptual landscape with which such things are classified and evaluated. 
one lives and acts in the correct and fine way (NE 10.8, 1178b23-9). It is in this way that virtue of character contributes to, or is operative in, the virtuous person's decisions and actions, making the agent decide and act for the sake of the right end (EE 3.1, 1230a27-32). This is, then, the reason why Aristotle defines it as hexis prohairetike : it is a habitual state of the non-rational part of the soul which makes one prone to making and acting on decisions (and in which, consequently, the non-rational part follows those decisions) in virtue of that part's standing in just the right relation to (correct) reason (namely, one that qualifies the agent as a true self-lover). If this interpretation is correct, then it should be noted that there is close affinity between the way in which the Aristotelian god moves, namely as object of love (Metaph. 12.7, 1072b3) and the way in which, on my interpretation, reason (or the rational part of the soul) holds authority over non-rational desires: it does so precisely because, for the virtuous agent, reason (or, more specifically, practical wisdom) is an object of love. In a way, this should not be surprising: the Aristotelian god is, after all, nous (e.g. Metaph. 12.9, 1074b34-1075a3). It might also be worth noting that since being loved is, on Aristotle's view, close to being honored ( $N E$ 8.8, 1159a15), Aristotle's virtue of character bears affinity, in its relation to practical wisdom, to Kant's notion of the respect for moral law.

\section{III}

In order to further clarify the view defended here, in the remainder of the paper I would like to consider some objections, limitations and caveats as well as various consequences and benefits of the interpretation I have proposed.

\section{Objections, Caveats and Limitations}

1. Jessica Moss has recently argued that virtue of character is a hexis prohairetike because it contributes to the decision-making process because it is responsible for the formation of wishes insofar as it is responsible for things appearing as good (or bad) to the agent. Although her argument is embedded in an overall interpretation of the nature of wish, ${ }^{56}$ her thesis heavily depends

${ }^{56}$ According to her account, wishes are distinguished from non-rational appetites insofar as the former are based on beliefs about the goodness of their objects, whereas the latter are based on mere appearance that the objects are good (Moss 2012, 225). The crucial step in her view is the claim that to believe that something is good is not connected to having reasons for thinking that it is good, as the standardly accepted model asserts (different versions of which can be found, for example, in Irwin 2007, 174; Cooper 1999b; Mele 1984; Broadie 1991, 107; or Charles 1984, 152) but, rather, to simply assenting to an appearance of something as good. Although such assent requires that one conceptualize the desired object as an end or goal, it does not require that one think that the object is good on the basis of some reasons, over above the appearance (Moss 2012, 37). Since the 
on appealing to EE 3.1,1230a27-32 where, as she argues, Aristotle tells us that virtue is a hexis prohairetikē because it 'gives one the right goal for one's decisions' (Moss 2012,166). As she says, virtue of character 'is a prohairetic state in that its function is to make decisions correct (cf. 1144a26-9), although because it controls only one component of decisions it needs help of something else - phronēsis - to fulfill its function' (ib.). If her interpretation of EE 3.1, 1230a27-32 is correct, it constitutes a serious objection to my account of the meaning of hexis prohairetike.$^{57}$ It will thus be useful to look at this passage:

But since all virtue is prohairetike - how we mean this, we have said before, namely that

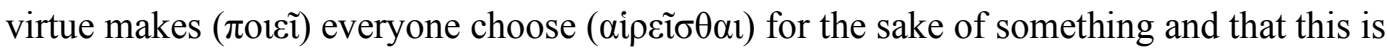
that for the sake of which, the fine - it is clear that also bravery, being a virtue, will make ( $\pi$ oiń $\sigma \varepsilon l)$ one endure fearful things for the sake of something so that [one endures them] neither due to ignorance - since virtue makes ( $\pi 01 \varepsilon \tilde{\imath})$ judging correct - nor due to pleasure, but because [doing so] is fine (if it is not fine but crazy, one does not endure since it would be shameful to do so).

It is notable that whether or not the passage supports the view that virtue provides the right goal (as Moss suggests), the passage stresses, and does so repeatedly, a rather different point, namely that virtue is prohairetike because it makes one decide and act (in the example, 'endure') for the sake of the right goal. That is not the same thing as saying that virtue provides the right goal for one's decisions. It is possible to claim that the role of virtue is to make one go for that goal, that is, to make one deliberate and decide (and then to $a c t$ ) for the sake of that goal, while maintaining that

appearance of something as good is explained by Moss in terms of perceptual pleasure (i.e. to appear good is to appear pleasant), wishes turn out to be dependent on feelings of pleasure and pain. And, since virtue of character determines the ways in which we experience pleasure and pain, it follows that virtue of character contributes to decisions insofar as it supplies the correct wishes. Moss's argument depends on accepting three theses: (1) virtue of character is the best state of only the non-rational part; (2) wish does not belong to the rational part or aspect of the soul; (3) Aristotle thinks that things can appear as good in perception. (1) can be supported by indisputable textual evidence at least in the $E E$ and it is certainly an interpretative option in the $N E$. For (2) see n. 13 above. For problems connected with (3), see Corcilius 2011, 122-7.

${ }^{57}$ It should be obvious that my interpretation of the central feature of Aristotle's conception of virtue of character, one that explains the way in which reason can directly hold authority over nonrational desires, does not depend on the further claim that it is this feature that is picked up by the phrase hexis prohairetike. I offer this further claim as, in my view, the best understanding of this undoubtedly difficult phrase. 
something else than virtue provides the goal (say, practical wisdom). ${ }^{58}$ In other words, the passage does not explicate the meaning of hexis prohairetike as being a state that provides the right ends or goals for one's decision but, rather, as being a state that makes or ensures that one decides and acts for the sake of the right goals. It is a further question (one that this paper tried to give an answer to), how virtue of character can in fact do so.

There is also a more general problem with her interpretation. If one accepts that hexis prohairetikē defines virtue of character, then virtue's characteristic activity (ergon) must be essentially tied to decisions or the decision-making process. On Moss's view, even as virtue of character contributes to the decision-making process insofar as it is responsible for the formation of wishes, the actual formation of decisions by deliberative processes that start from those wishes is not in any discernable way the work (ergon) of virtue of character but of practical wisdom. In fact, one could argue that, on Moss's view, Aristotle should have defined virtue of character as hexis orektike since what it does is to regulate all desires. ${ }^{59}$ The fact that some of the appropriate desires to which virtue of character gives rise result in decisions seems to be an independent result, one that occurs when some of those desires (namely certain wishes) become targets of practical thinking. ${ }^{60}$

2. The interpretation I have proposed does not resolve the often-debated issue of whether it is practical wisdom or moral virtue (or, alternatively, reason or non-rational desires) that supplies the

${ }^{58}$ Similar understanding of the passage can be found already in Loening 1903, 115.

${ }^{59}$ The Magna Moralia defines practical wisdom as hexis praktikē kai prohairetike (MM 1.34, $1197 \mathrm{a} 14)$ while virtue of character is characterized simply as a mean state of certain feelings (MM 1.8, 1186a33). It is a challenge for many interpretations, including Moss 2012, to explain why, given the division of labor between the two parts of the soul, the $M M$ definitions are not in fact better. See also 'Consequences and Benefits' 3, below.

${ }^{60}$ Concerning this point, Moss argues that just as 'eyes are for seeing' even if seeing requires the help of brain, so it can be the function of virtue to make decisions correct, even if they require the help of practical wisdom to do so. But the analogy with eyes is not quite on the mark. Unlike the brain, eyes have a unique relationship to seeing. They are the organ of visual perception and are distinguished (as an organ) by their role in helping us see ( $D A 415 \mathrm{~b} 33$ ) whereas the brain (or, for Aristotle, heart: 647a22-b9) has many different cognitive functions, only one of which is perception. In other words, it is the brain that requires the help of eyes to see, not the other way round. The analogy, then, would point rather to practical wisdom as the state that issues in decisions since practical wisdom has the more unique relationship to decisions (i.e. is like the eyes): it makes us deliberate well, and deliberation is done specifically in order to make a decision. Virtue of character would be more like the brain (or heart) in that it would be only one of its functions (erga) to contribute to decisions - it would do so through its general function of regulating the way in which things appear to us. 
goals for one's actions. ${ }^{61}$ In fact, it is compatible with both sides of the debate. ${ }^{62}$ On any view of Aristotle, it is uncontroversial that reason plays a significant role in shaping what and how we desire. It might well be, for example, that one's long-term commitment to health (i.e. one's being a health-conscious person), to honor or to virtue has been acquired through upbringing and habituation or through some experience (say, that of illness) that instilled in one the appropriate commitment (to being healthy or honorable or virtuous) in a non-rational way (whether justifiable or not). That still leaves plenty of room for reason to play a leading role - in figuring out both what being healthy amounts to and what ways of ensuring one stays healthy are to be taken, and in directing one's desires (on the basis of reason) towards healthy and away from unhealthy things. After all, one's commitment to health might run against at least some of one's likes and dislikes, especially as what is healthy changes as one's life progresses. Hence, even on a view according to which it is character (or moral virtue) that ultimately sets the goals, it still is the case (even if in a restricted way), and a reasonable thing for Aristotle to say, that the non-rational part should (and in a virtuous person does) live according to reason. Even Jessica Moss, a prominent defender of this view, says that 'proper habituation trains the non-rational part to obey and wait on the rational part. Thus it trains one to aim at fine things in a special way - namely, in such a way that one's nonrational impulses will wait on the deliverances of deliberation before pursuing them' (Moss 2012, 210).

${ }^{61}$ This debate dates back to the publication of Walter 1874 who argued against then prevalent scholarly opinion that it is the task of reason, in particular, of practical reason, to determine and both set the goals (including the highest good) and discover the means by which to achieve them. Walter's thesis was that it is rather moral virtue (and hence non-rational desires) that determines and sets the goals or ends and, hence, that the goals or ends are set through habituation. The role of practical reason is exhausted in the calculation of the means towards the goals. Walter's view was opposed by Loening 1903. Loening distinguished between the contribution of practical reason, which 'besteht in der Erkenntnis eines Dings als eines Guten, d. h. al seines solchen, welches wert ist, begehrt oder dem Handeln als Zweck gesetzt zu warden' (33), and that of desire, which being 'wachgerufen' through this act of reason, sets 'das erkannte Gute . . zum Zweck des Handelns' (35). For Loening, then, practical reason not only determines the means but also, and in addition, determines (the content of) the end or goal although it is desire that then seizes upon such determination to make it a motive for action. Loening's view became known to the Anglophone scholarship through Allan 1953, and has been since (in one way or another) the prevalent view of the matter. See, for example: Cooper 1975; Irwin 1975; Wiggins 1980; Dahl 1984. Opposing views, more akin to those of Walter, include Aubenque 1965; Natali 1988; and Moss 2012.

${ }^{62}$ It should be emphasized that the view I defend neither asserts nor denies that the virtuous person's non-rational desires are involved in all actions. It merely asserts that, whenever such desires are involved in the virtuous person's actions, they are sensitive to reason in the way I have described. 
However, my interpretation suggests that Aristotle's concern is perhaps not so much the question at the center of this long-standing debate, but rather the conditions under which the nonrational side of the human soul becomes both integrated with, and guided by, the rational side so as not only not to hinder but to actively contribute to and motivate the rational pursuit of the good life. ${ }^{63}$ As he sees it, such integration and guidance can only occur when reason is in a position not only to impart information but also to impart or effect motivation onto the non-rational side. ${ }^{64}$ And this is possible only if the non-rational side becomes re-oriented towards reason in such a way that one becomes a genuine lover of (true) reason. It is only then that one becomes receptive to

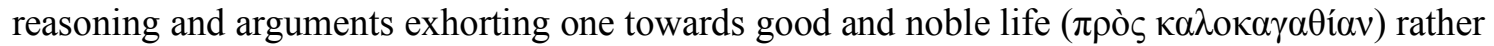
than merely obeying the law out of fear of punishment while, at the same time, trying to pursue the changing pleasures of the moment as one's feelings dictate (NE 10.9, 1179b1-15).

3. My interpretation does not shed decisive light on Aristotle's assertion that one cannot be practically wise without being virtuous and vice versa ${ }^{65}$ In order to do so, one would also need to offer an analysis of Aristotle's conception of practical wisdom. Nevertheless, see 'Consequences and Benefits' 4 (below).

4. I have criticized interpretations, such as those by Lorenz 2006 and Cooper 1999b, which in different ways claim that the way in which reason controls non-rational desires involves a

${ }^{63}$ This point is perhaps best expressed in a passage in the Magna Moralia: 'And so there is acting in

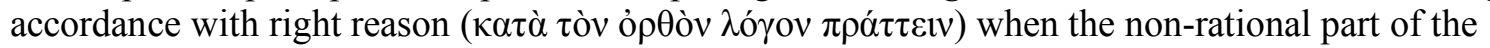

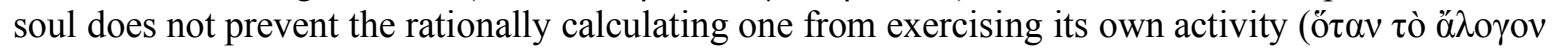

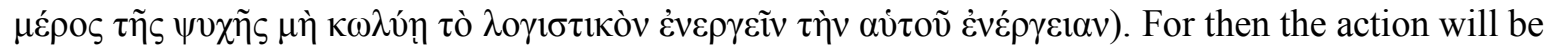
in accordance with right reason. Since we have a worse and a better part in the soul and the worse is always for the sake of the better - just as in the case of body and soul the body is for the sake of the soul, and we say that we have the body in a good state ( $\kappa \alpha \lambda \tilde{\omega} \varsigma)$, when it is such as not only not to

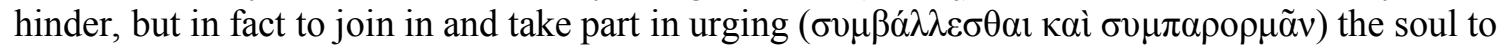
accomplish its own work (since for the worse to be for the sake of the better is for it to aid the better in its work) - it is when the feelings do not hinder reason from exercising its own work (ö $\tau \alpha v$ oṽv

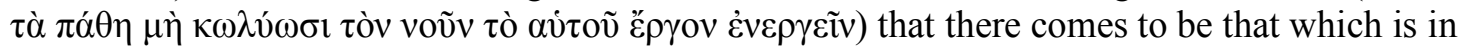
accordance with right reason' (MM 2.10, 1208a10-20).

${ }^{64}$ Price $2011 a$ remarks that the way in which reason is supposed to 'persuade' non-rational desires 'must fall within a spectrum of possibilities: (i) directing attention; (ii) imparting information; (iii) convincing by giving reasons' (119 n. 15). Following Lorenz 2006, he excludes (iii), while preferring options (i) and (ii). But, as I have argued, the virtuous agent's reason is in a position (due to the right orientation of the non-rational side) to impart not only information but also motivation.

${ }^{65}$ On this question, see esp. Coope 2012. 
mechanism for drawing their attention to various relevant (i.e. pleasant or painful) features or consequences, either of the good actions proposed by reason, or the bad desired objects. But I have not denied that such mechanisms are available to Aristotelian agents. In fact, it is perfectly possible (even very likely) that it is precisely such mechanisms that are employed (with different degrees of success) by both the self-controlled and the uncontrolled person in their attempts to manage their unruly desires.

5. One frequent way in which Aristotle characterizes virtues of character is that they are concerned with actions and feelings and so also with pleasures and pains (NE 2.3, 1104b13-15). They thus concern one's relations to external goods (such as wealth or honor) as well as to goods of the body. In view of this, one might object that, in characterizing of virtue of character as (centrally) a state in which one is disposed to enjoy and engage in deliberating and making and executing one's decisions, I have underplayed or even overlooked this aspect of virtue of character, one that is central to Aristotle's discussion of virtue in NE 2. In reply, it is sufficient to point out that, in saying that the central task of virtue of character has to do with decisions, I do not mean to say that that is its only task. Virtues of character obviously concern one's relation to external goods and bodily pleasures - but that concern divides virtue of character into different kinds, whereas the concern I highlighted is what is common to all virtues of character. Hence, although it is true that virtue of character is responsible for the way things appear to us (a point rightly emphasized by Jessica Moss), this responsibility is not the function of virtue of character as such. Rather, it is distributed among the functions of various particular virtues as they deal with different objects and different kinds of pleasures and pains. The particular virtues of character are in fact different ways in which

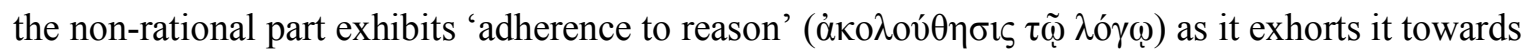
the right things (EE 3.1, 1229a1-3).

\section{Consequences and Benefits}

1. The proposed understanding of the meaning of hexis prohairetike makes it clear that virtue of character is a state of one's motivational propensities (i.e. the best state of the non-rational part of the soul that Aristotle characterizes as desiderative). It is a state that makes one prone to deliberating in order to make decisions and in which one's non-rational desires follow or adjust according to such decisions. This might seem an obvious point, but it is sometimes missed. For example, Lorenz argues that hexis prohairetike is a state of one's soul which makes one capable of 
or suited for making decisions (Lorenz 2009, 194). Yet, it should be reason that makes one capable of (or suited for) making decisions since reason is the requisite cognitive capacity. ${ }^{66}$

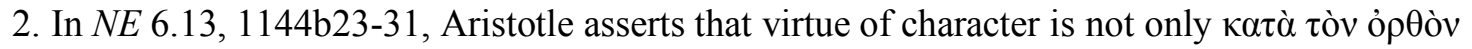

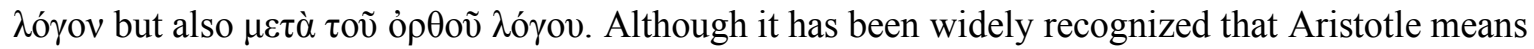
that the relation between the virtuous person's reason and her non-rational desires is more intimate than mere correspondence, scholars have often puzzled about what more is involved, especially as Aristotle is not particularly forthcoming about the precise meaning of his claim. ${ }^{67}$ Moreover, the assertion creates a tension with Aristotle's characterization of the part of the soul that is the provenance of virtue of character as non-rational, since meta logou is often used by Aristotle in relation to intellectual states to characterize them as such (i.e. as rational). ${ }^{68}$ However, if my account is correct, the phrase can be explained in a relatively straightforward way, namely as a contrast between virtue of character being merely 'in accordance with logos' and its being such as to go 'along with' or 'be attached to' reason, that is, to follow reason's commands. This is a sense of being 'meta logou' recognized by Aristotle at Probl. 949b22-3, where he contrasts it with a sense in which uncontrolled anger is 'meta logou', namely when it reacts to information provided by reason, but not to its commands (which is the other, virtuous sense, of 'meta logou'). The virtuous agent's non-rational desires and feelings follow reason insofar as they appropriately adjust themselves according to reason's deliberation even if their attachment does not flow from being rationally

${ }^{66}$ Lorenz infers his interpretation partly by analogy with epistēmē which Aristotle defines as hexis apodeiktike, that is, a state that makes one capable of producing demonstrations or proofs. But although this understanding makes sense for epistēme (as the best state of one's cognitive capacity to know or understand), it makes less sense for what is essentially a conative capacity.

${ }^{67}$ As Paula Gottlieb points out, it is clear that, in order for 'ethical virtue to involve the correct reason, then, the functions of both parts of the soul must be intimately connected' while, at the same time, 'Aristotle's account of the integration is sketchy' (Gottlieb 2009, 104-5).

${ }^{68}$ Thus, craft (NE 6.4, 1140a20-1; Metaph. 9.2, 1046a36-b1), practical wisdom (NE 6.5, 1140b20$1)$ as well as scientific knowledge $(N E 6.6,1140 \mathrm{~b} 33)$ are described as being meta logou. Lorenz 2009 takes this as evidence for the view that virtue of character is rational (i.e. on his view, involving practical wisdom). However, Moss 2012, 168-9 argues against that inference by pointing out that, among other things, appetites are characterized as meta logou in Rhet. 1370a18-27. In that passage, the appetites are meta logou because they resulted from 'having listened or been persuaded', which is a description that mirrors the way Aristotle describes non-rational desires in $N E 1.13$ and $E E 2$ 2.1. For a discussion of the meaning of meta logou as it pertains to the intellectual states listed above (and esp. to practical wisdom), see Moss 2014. 
persuaded but, rather, because the agent has formed a stable, non-rational attachment to his deliberative processes (e.g. Rhet. 1370a18-27; MA 702a12-17).

3. The proposed interpretation offers a natural way to explain the connection between (a) the requirement that the virtuous person enjoys virtuous actions and (b) the requirement that she decides on them for themselves. Since the non-rational part of the soul's basic orientation is towards reason (in the way I explained it), the virtuous person finds it satisfying (or enjoyable) to deliberate and make decisions. It is a consequence of this motivational propensity that she enjoys her actions as (or in the way that) she has decided on them. Hence, enjoying virtuous actions is not a precondition or presupposition for deciding on them for themselves (as the standard account, exemplified for example by Hutchinson 1986, would have it) but a consequence of her (nonrational) attachment to true practical reasoning. The virtuous agent enjoys them insofar as she has correctly decided on them. This account is precisely consistent with what Aristotle says about the painful actions of the brave person (NE 3.9, 1117b1-17). It would be bizarre to claim that the brave person enjoys the painful blows or injuries she receives in fighting. However, on the proposed interpretation, the virtuous agent centrally enjoys acting correctly in accordance with her true reasoning. Thus, even if the action is painful, she still finds it satisfying (and pleasant) to have decided on it for the right reasons and enjoys that very fact. ${ }^{69}$ Moreover, since the identity of actions is determined by their goals (or reasons for which one does them), what she finds pleasant, even in the case of painful actions, is reaching that goal (or keeping in accordance with her reason for acting as she does) (NE 3.9, 1117b15-21).

4. On at least some interpretations of ethical development in Aristotle, the virtuous agent first reaches more or less full development of her non-rational part - she acquires, in Burnyeat's words, the that (Burnyeat 1980,74) - she learns, through habituation, what is just and noble in such a way

${ }^{69}$ This is where Howard Curzer, who argues that virtuous actions are somewhat pleasant but mostly painful overall (Curzer 2002, 150-4), goes wrong. He is right, of course, that the actions might involve pain but the point is that insofar as they are virtuous, they are, for the virtuous person, pleasant or satisfying. And this can be so always because what makes them virtuous is, primarily, the fact that they are actions chosen and done in accordance with true reasoning. Of course, this fact about them might not be pleasant or satisfying at all for any other type of agent, but it is so for the virtuous person precisely because, for her, the concern with (or love of) knowledge, and correct reasoning and deliberation is the central concern of her character. Given our modern skepticism about the motivational power of knowledge (as well as philosophy), this view might not sound plausible to us but it is a view that many Ancient philosophers would certainly not find incredible. 
that it becomes her second nature. This stage is then completed by the acquisition of practical wisdom which provides the why - the understanding 'which alone can accomplish the final correcting and perfecting of your perception of "the that" (ib.). There is something distinctly odd in this picture - it leaves one with the sense that the development of the non-rational part, insofar as the habituation of that part is concerned, is (and in fact must be) finished before one can acquire practical wisdom. This could give rise to a doubt: if habituation was to go just right, would one even need practical wisdom? As is well-known, Aristotle resists this argument (NE 6.12, 1144a12-37). It is worth noting that, on the proposed interpretation, the habituation to virtue of character and the acquisition of practical wisdom go hand in hand. Since virtue of character is centrally habitual 'love of practical wisdom', habituation to virtue cannot even get off the ground without simultaneous development of practical wisdom.

5. It is a consequence of the proposed interpretation of the meaning of hexis prohairetike that, unlike virtue, vice is not a hexis prohairetikē. This is not the usual view. For example, Richard Bodeüs writes that, although the description of virtue as prohairetike might be a bit obscure, 'il est évident que la même caractéristique appartient à l'état vicieux' (Bodeüs 2004, 116), while Karen Nielsen claims that Aristotle refuses 'to call a state a vice unless it is a $\check{\varepsilon} \xi 1 \zeta \pi \rho \circ \alpha \iota \rho \varepsilon \tau 1 \kappa \eta ́$ ' (Nielsen 2017, 6 n. 12). Presumably, the view comes from Aristotle's assertions to the effect that the vicious person decides to act viciously. ${ }^{70}$ However, it is notable that Aristotle never asserts that vice (or any other state than virtue) is a hexis prohairetike. One passage often cited in support of the view is $E E$ 3.7, 1234a24-34. In this passage, Aristotle contrasts certain motivational states that he calls 'natural' (righteous indignation, modesty, friendliness, sincerity, dignity or wit) with virtues. Unlike virtues, these states are inborn (natural) ways of feeling in certain ways which, however, do not relate to any particular actions on their own. Hence, they cannot give rise, by themselves, to decisions and can lead to action only indirectly, insofar as they contribute to some other states

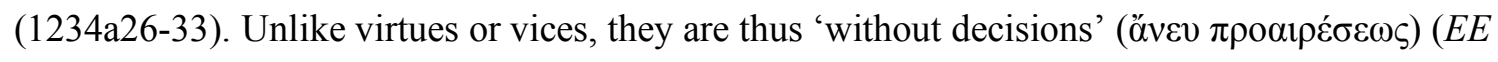
$3.7,1234 \mathrm{a} 26$ ). But this need not mean more than that virtues and vices involve (or can directly lead to) actions on decisions. If so, the passage says nothing about virtue (or vice) being a hexis prohairetike. . Beyond the passage in EE 3.7, however, the support for the view is thin at best. ${ }^{71}$ In

${ }^{70} N E$ 7.3, 1146b18-24; 7.4, 1148a15-20; 7.7, 1150a17-25; 7.8, 1150b29-1151a7.

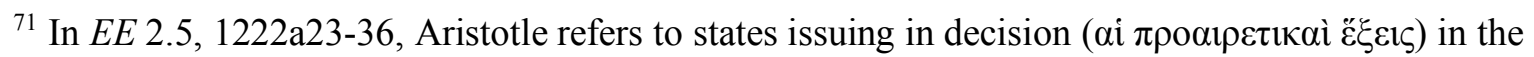
context of discussing the idea that sometimes one of the extreme habitual states is more opposed to the mean (i.e. the excellent) habitual state that the other extreme (1222a23-8). Aristotle illustrates 
fact, in the one passage in which Aristotle could have easily asserted it, he conspicuously avoids doing so, applying the term to virtues only (EE 3.1, 1228a22-5):

In general terms, then, it has been stated that the virtues involve mean points and that they issue in decisions ( $\left.\pi \rho \alpha_{1} \rho \varepsilon \tau 1 \kappa \alpha i\right)$, and that their opposites are vices, and what these are.

The benefit of the proposed interpretation is that it explains why Aristotle refrains from saying that

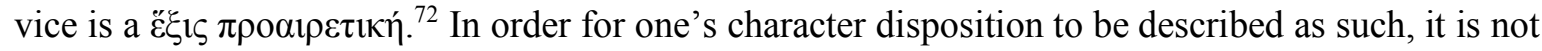
enough that one acts on decisions. Rather, one must be a lover of truth and knowledge, of deliberating and decision-making. Aristotle never characterizes the vicious person in those terms. Far from it, the vicious person's reasoning is characterized as being in the service of her appetites and feelings (e.g. 1168b15-7). It is her non-rational desires that rule reason and, hence, that control and rule the person. Insofar as that is the case, given the inexhaustible ways in which vice can manifest itself ( $N E 2.6,1106 \mathrm{~b} 28-34)$, vice has no central concern of the desires of which it is the state (other than whatever appears pleasant to a particular person who has them) by which it could be defined: it might be a disposition of one's desires, but it is one that can lie in any of the various available extremes as they arise in different regions (one can be intemperate and coward and stingy, but also intemperate, rash, and wasteful and so on). Vice is thus not an appropriately unified state of

the point with the example of the body, for which 'excess in exercise is healthier than its deficiency and closer to the mean, but in diet, deficiency is healthier than excess' (1222a29-31). He then goes

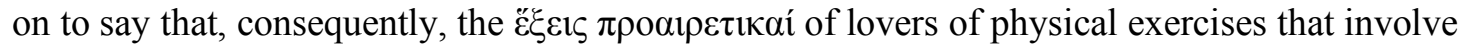
intense exercise or strict diet are more supportive of health than those that involve the other extremes. It is not obvious whether the $\check{\varepsilon} \xi \varepsilon 1 \varsigma \pi \rho 0 \alpha \iota \rho \varepsilon \tau 1 \kappa \alpha$ in question are (1) temperance and its corresponding extremes; (2) virtues (i.e. so that, for example, the claim would be that in lovers of physical activities temperance contributes more to health than bravery); (3) any states of character (so that the claim would be that, for example, rashness contributes more to health than cowardice would); or even (4) habits of lovers of physical activities that do not have to do with character. The unclarity is rooted not only in the hard-to-parse text but also in the fact that, so far as the best condition of the body is concerned, the standard according to which both exercise and diet are to be executed is health. But that is a medical standard (1249a21-1249b23) and not a standard for living a virtuous life. Health might be a consequence of temperance but it is not its standard or measure (1248b23-4). Moreover, unlike for diet, there does not appear to be any clear candidate for virtue of character that is concerned with physical exercise. The reference to $\check{\varepsilon} \xi \varepsilon 1 \varsigma \pi \rho о \alpha \iota \rho \varepsilon \tau \iota \kappa \alpha i$ in the passage is thus too obscure to support any particular view.

${ }^{72}$ Since it is beyond the scope of this paper to investigate this issue further, I have constrained my remarks to vice, leaving the complicated cases of self-controlled and lack of control aside. 
the non-rational part at all. ${ }^{73}$ The vicious person might make decisions to act as she does, but she has no special concern with acting on deliberation or decision - her life is not a life kata logos but kata pathos (NE 6.8, 1169a5).

6. Kosman 1980 raises the following puzzle. Aristotle tells us that virtue of character has to do with actions and feelings. But the definition of virtue of character in terms of decisions can only plausibly apply to actions: Aristotle says that we have feelings ả $\pi \rho 0 \alpha 1 \rho \varepsilon ́ \tau \omega \varsigma ~(N E ~ 2.5 .1106 a 2)$. In specifying the central focus of non-rational desires and feelings in reason and deliberation, the proposed interpretation not only explains how the definition applies to feelings but also how feelings can be sensitive to one's deliberation and decisions even if we do not decide to have them. ${ }^{74}$

7. Angioni 2009 raises another puzzle: given that virtue is repeatedly said to be concerned with actions rather than with decisions, why is virtue of character defined as hexis prohairetike rather than as hexis praktike kai prohairetikēe ${ }^{75}$ A similar puzzle could also be formulated in relation to practical wisdom: one could wonder why practical wisdom is defined as hexis praktikē (NE 6.5, $1140 \mathrm{~b} 5)$ rather than as prohairetike. After all, Aristotle associates practical wisdom with deliberation (which concludes, if successful, in decision), while virtue of character is said to be concerned with actions. My interpretation allows for a good explanation. In each case, the virtuous state is defined by the focal point or object of the activities it shapes. For practical wisdom, it is the fact that deliberation is primarily a cognitive process (a kind of inquiry) that seeks and determines what action one is to do rather than one that makes decisions (even as these follow from successful deliberation). Hence, practical wisdom is a state which makes one (cognitively) capable of finding

${ }^{73}$ I defend a view of vice along these lines in Müller 2015.

${ }^{74}$ Kosman argues that feelings can be chosen in an indirect way: it is "possible to engage in a certain range of conduct deliberately designed to make one the kind of person who will characteristically feel in appropriate ways, at appropriate times, and so on. And in this sense, feelings are deliberate and chosen, since the hexeis from which these feelings emanate are deliberate and chosen, since (in turn) the actions that lead to these hexeis are deliberate and chosen, and deliberately chosen to make one the kind of person who characteristically will have the appropriate feelings' (Kosman 1980, 113).

${ }^{75}$ Angioni argues that the omission of 'praktike' is only apparent since the fact that virtue is concerned with action is already contained in its being a state (hexis): "to say that moral virtue is a hexis, in this context, involves assuming that moral virtue is a disposition to practice virtuous actions' (Angioni 2009, 8). 
or determining the best action to take. On the other hand, virtue of character is a state that motivates us to do actions in a specific way, namely on the basis of deliberation and decisions. It is acting in that way that distinguishes virtue of character and the proposed interpretation explains how it can do so. ${ }^{76}$

\section{Bibliography}

Allan, D. J. (1953), ‘Aristotle's Account of the Origin of Moral Principles', Actes du XIe Congrès Internationale de Philosophie 12: 120-7. [Reprinted in J. Barnes, M. Schofield and R. Sorabji (eds.) Essays on Aristotle vol. 2 (London, 1977), 72-8.]

Angioni, L. (2009), 'Notas sobre a definição de virtude moral em Aristóteles (EN 1106b361107a2)', Journal of Ancient Philosophy 3: 1-17.

Annas, J. (1993), The Morality of Happiness. Oxford.

Anscombe, G. E. M. (1965), 'Thought and Action in Aristotle' in R. Bambrough (ed.), New Essays on Plato and Aristotle (London), 143-58.

Aubenque, P. (1965), 'La prudence aristotélicienne porte-t-elle sur la fin ou sur les moyens?', Revue des Études Grecques 78: 40-51.

Bobonich, C. (1991), 'Persuasion, Compulsion and Freedom in Plato's Laws', The Classical Quaterly 41: 365-88.

Bodeüs, R. (2004), Aristote. Éthique à Nicomaque. Paris.

Broadie, S. (1991), Ethics with Aristotle. Oxford.

Burnyeat, M. F. (1980), 'Aristotle on Learning to be Good' in A. O. Rorty (ed.), Essays on Aristotle's Ethics (Berkeley), 69-92.

Cagnoli Fiecconi, E. (2018), ‘Aristotle on the Structure of Akratic Action', Phronesis 63: 229-56. Caston, V. (2002), 'Aristotle on consciousness', Mind 111: 751-815.

${ }^{76}$ I would like to thank Jessica Moss, Naly Thaler and the anonymous reviewer for very helpful comments on this paper. At various earlier stages of this paper, I have also benefitted from comments and questions of audiences at UCLA, Renmin University of China, Catholic University in Ružomberok, NYU, and the Pacific APA 2017. 
Charles, D. (1984), Aristotle's Theory of Action. Ithaca.

Charles, D. (2015), 'Aristotle on Practical and Theoretical Knowledge', in D. Henry and K. M.

Nielsen, Bridging the Gap Between Aristotle's Science and Ethics (Cambridge), 71-93.

Coope, U. (2012), 'Why does Aristotle think that ethical virtue is required for practical wisdom?',

Phronesis 57: 142-63.

Cooper, J. (1975), Reason and Human Good in Aristotle. Cambridge.

Cooper, J. (1999a), Reason and Emotion: Essays on Ancient Moral Psychology and Ethical Theory.

Princeton.

Cooper, J. (1999b), ‘Some Remarks on Aristotle’s Moral Psychology’ in Cooper 1999a, 237-52.

Cooper, J. (1999c), ‘An Aristotelian Theory of the Emotions’ in Cooper 1999a, 406-45.

Corcilius, K. (2008), Streben und Bewegen: Aristoteles' Theorie der animalischen Ortsbewegung.

Berlin.

Corcilius, K. (2011), 'Aristotle's Definition of Non-Rational Pleasure and Pain and Desire' in J.

Miller (ed.), Aristotle's Nicomachean Ethics: A Critical Guide (Cambridge), 117-43.

Curzer, H. J. (2002), 'Aristotle's Painful Path to Virtue', Journal of the History of Philosophy 40: 141-62.

Dahl, N. O. (1984), Practical Reason, Aristotle, and Weakness of Will. Minneapolis.

Fortenbaugh, W. W. (2002), Aristotle on Emotion. $2^{\text {nd }}$ edn. London.

Gourinat, J.-B. (2002), 'Délibération et choix dans l'éthique aristotélicienne' in G. Aubry and G.

Romeyer-Dherbey (eds.), L'excellence de la vie: sur l'éthique à Nicomaque et l'éthique à Eudème d'Aristote (Paris), 95-124.

Gottlieb, P. (2009), The Virtue of Aristotle's Ethics. Cambridge.

Grönroos, G. (2007), 'Listening to Reason in Aristotle's Moral Psychology', Oxford Studies in Ancient Philosophy 32: 251-71.

Grönroos, G. (2015), 'Wish, Motivation and the Human Good in Aristotle', Phronesis 60: 60-87.

Hutchinson, D. S. (1986), The Virtues of Aristotle. London.

Irwin, T. H. (1975), 'Aristotle on Reason, Desire, and Virtue', Journal of Philosophy 72: 567-78. 
Irwin, T. H. (2007), The Development of Ethics: A Historical and Critical Study. Oxford.

Kennett J. and M. Smith (1996), 'Frog and Toad Lose Control', Analysis 56: 63-73.

Kosman, L. A. (1980), 'Being Properly Affected: Virtues and Feelings in Aristotle's Ethics' in A.

O. Rorty (ed.), Essays on Aristotle's Ethics (Berkeley), 103-16.

Lawrence, G. (2011), 'Acquiring Character: Becoming Grown-Up' in M. Pakaluk and G. Pearson (eds.), Moral Psychology and Human Action in Aristotle (Oxford), 233-83.

Liu, W. (2012), 'Creating Character: Aristotle on Habituation, the Cognitive Power of Emotion, and the Role of Prudence', Frontiers of Philosophy in China 7: 533-49.

Liu, W. (2016), 'Aristotle on Prohairesis', Labyrinth 18: 50-74.

Loening, R. (1903), Die Zurechnungslehre des Aristoteles. Jena.

Lorenz, H. (2006), The Brute Within: Appetitive Desire in Plato and Aristotle. Oxford.

Lorenz, H. (2009), 'Virtue of Character in Aristotle's Nicomachean Ethics', Oxford Studies in Ancient Philosophy 37: 177-212.

McDowell, J. (1998), 'Some Issues in Aristotle's Moral Psychology’ in S. Everson (ed.), Ethics (Cambridge), 107-28.

Mele, A. (1981), 'Choice and Virtue in the Nicomachean Ethics', Journal of the History of Philosophy 19: 405-23.

Mele, A. (1984), 'Aristotle’s Wish', Journal of the History of Philosophy 22: 139-56.

Mele, A. (1997), 'Underestimating Self-control: Kennett and Smith on Frog and Toad', Analysis 57: 119-23.

Morel, P.-M. (2017), 'Vertu éthique et rationalité pratique chez Aristote. Note sur la notion d'hexis proairetikê', Philonsorbonne 11: 141-53.

Moss, J. (2012), Aristotle on the Apparent Good: Perception, Phantasia, Thought, and Desire. Oxford.

Moss, J. (2014), 'Right Reason in Plato and Aristotle: On the Meaning of Logos', Phronesis 59: 181-230.

Müller, A. W. (1982), Praktisches Folgern und Selbsgestaltung nach Aristoteles. Freiburg / München. 
Müller, J. (2015), 'Aristotle on Vice', British Journal for the History of Philosophy 23: 459-77.

Müller, J. (2016), 'What Aristotelian Decisions Cannot Be’, Ancient Philosophy 36: 173-95.

Natali, C. (1988), 'Les fins et les moyens: un puzzle aristotélicien', Revue de Philosophie Ancienne 6: $107-46$.

Natali, C. (2001), The Wisdom of Aristotle. Albany.

Natali, C. (2016), 'La vertu selon Aristote' in E. Berti and M. Crubellier (eds.), Lire Aristote (Paris), 61-175.

Nielsen, K. M. (2017), 'Vice in the Nicomachean Ethics', Phronesis 62: 1-25.

Pakaluk, M. (2005), Aristotle's Nicomachean Ethics: An Introduction. Cambridge.

Price, A. W. (2011a), Virtue and Reason in Plato and Aristotle. Oxford.

Price, A. W. (2011b), 'Aristotle on the Ends of Deliberation' in M. Pakaluk and G. Pearson (eds.), Moral Psychology and Human Action in Aristotle (Oxford), 135-58.

Rapp C. (2002), Aristoteles: Rhetorik. Berlin.

Reeve, C. D. C. (2013), Aristotle on Practical Wisdom. Cambridge, Mass.

Segvić, H. (2009), 'Deliberation and Choice in Aristotle' in From Protagoras to Aristotle: Essays in Ancient Moral Philosophy (Princeton), 144-71.

Sorabji, R. (1980), 'Aristotle on the Role of Intellect in Virtue' in A. O. Rorty (ed.) Essays on Aristotle's Ethics (Berkeley), 201-19.

Sripada, C. (2014), 'How is Willpower Possible? The Puzzle of Synchronic Self-control and the Divided Mind', Noûs 48: 41-74.

Smith, A. D. (1996), 'Character and Intellect in Aristotle's Ethics', Phronesis 41: 56-74.

Viano, C. (2002), 'Passions, désirs et plaisirs de rivalité chez Aristote' in G. Aubry (ed.)

L'Excellence de la vie. Sur l'Ethique à Nicomaque et l'Ethique à Eudème d'Aristote (Paris), 237-

52.

Walter, J. (1874), Die Lehre von der praktischen Vernunft in der griechischen Philosophie. Jena.

Warren, J. (2014), The Pleasures of Reason in Plato, Aristotle, and the Hellenistic Hedonists. Cambridge. 
Wiggins, D. (1980), 'Deliberation and Practical Reason' in A. O. Rorty (ed.), Essays on Aristotle's Ethics (Berkeley), 221-40.

Williams, B. (1981), 'Utilitarianism and Moral Self-Indulgence' in his Moral Luck (Cambridge), 40-53.

Winters, J., Christoff, K. and Gorzalka, B. B. (2009), 'Conscious Regulation of Sexual Arousal in Men' The Journal of Sex Research 46: 330-43. 